\title{
The Prospect From Rugman's Row: The Row House in Late Sixteenth- and Early Seventeenth-Century London
}

\author{
By ROGER H. LEECH
}

Study of the development of the town house in London has focused mainly on the period following the Great Fire, and only latterly for the first time on the medieval period. The differences between building practice and concepts in London before and after the Fire have been over emphasized, obscuring a pattern of evolution and continuity in which phenomena generally taken to be of the mid-or later seventeenth century have rather earlier origins. Timber-framed row houses built in the last decade of the sixteenth century conformed to a well established medieval patterm. The first brick row houses of the early seventeenth century, including some of back to back plan, were part of this same tradition. The emphasis on improvement characteristic of many later building promotions was already evident in early seventeenth-century estate management. The term 'terrace' has been misused, giving the mistaken impression that the brick houses of post-Fire London were somehow a new phenomena. The large scale speculative building of row houses in post-Fire London had antecedents not only in the 1620s onwards, but in the sixteenth and earlier centuries.

\section{INTRODUCTION}

It has been said that 'every great centre of population has worked out a set of elementary answers - and has an unfortunate tendency to stick to them out of the force of inertia which is one of the great artisans of history' (Braudel 198I, 56I). This is no more so than in the humble realities of everyday life, and, where an alternative view has been projected, then close scrutiny may be needed. The purpose of this paper is to examine one such claim, made in the context of the development of the urban house in late sixteenth- and early seventeenth-century London.

Summerson provided the first overview of housing development in Georgian London. The setting and 'foundation stones' for this story were placed in the third decade of the seventeenth century, with Inigo Jones and the introduction of taste into England, followed closely by the noble speculator and the need for new building following the fire. The 'piazzas' of Covent Garden and the small number of preRestoration schemes were the precursors of the post-fire builders, notably Nicholas Barbon (Summerson 1969, 27-51).

These twin paradigms, one the introduction of taste into England, the other the post-Great Fire rebuilding, have continued to dominate thinking on the origins and development of the Georgian city, seeing the seventeenth century and these events in 
particular as a cultural break in the building of urban houses in the metropolis (see for instance Downes 1979, 8-9 et al., Cruickshank and Burton I990, xiii-xv).

In one sense though it would be surprising if the foundations of Georgian urban house building were to be found only in the seventeenth century. In an urban context most Georgian town houses were built as part of a continuous row. Where such rows have been of a generally uniform nature, they are now invariably referred to by architectural historians as 'terraces'. The uniformity of the houses within such rows varies considerably, reflecting the covenants of building leases and the degree to which particular builders were responsible for groups of individual plots. Speculative building such as this has a long history, extending back to the earlier middle ages.

For the fourteenth century several examples of rows of houses or shops built as a single structural unit can be cited. In York there are Lady Row built c. I 3 r6, nos. 54-60 Stonegate c. 1335, Coney Street by St Martin's and nos. I2-I5 Newgate, all partly extant. At least three other rows in York are known of from records (Short 1980; RCHME $198 \mathrm{I}$, lix). For the fifteenth century there are recorded examples from towns in the south-east and midlands, nos. 5-8 Turnagain Lane, Canterbury (Bowen 1986, 225-26), nos. 25-28 Barrow Street, Much Wenlock, built c. I435 (Moran I994, 32), Butchers Row, Shrewsbury (ibid.), nos. I 57-62 Spon Street Coventry (Jones and Smith I96I, 23-25), nos. 34-50 Church Street, Tewkesbury of c. I450 (Jones I968). In London no rows of medieval date survive, but there are a number of recorded examples; these include the two rows of shops, 20 and 18 in number, built for the Dean and Chapter of St Paul's in I 369 and I 370, and the two rows of shops built for the Prior of Lewes in 1373 (Salzman $1967,441-48$ ). Slightly later in date was the row in Abchurch Lane built shortly before 1390 (Schofield $1987,100-03$ and below). In thirteenth- and fourteenth-century London the "terrace-like row made up of units with a shop on the ground floor and rooms above was a standard feature of the London street scene' (Keene 1990, 36). Questions to be answered must include whether the building of such rows continued into the sixteenth and early seventeenth centuries, and, if so, were these building activities part of the same cultural tradition as the speculative building visible on a large scale in later seventeenth-century London.

In describing these medieval developments, the term 'row' has been used advisedly. In medieval and sixteenth-century England the term 'row', or 'rangia', was applied to a range of houses with a common identity, most notably a group of adjoining houses or shops where a particular trade was predominant. Paternoster Row, London, 'paternosterrewe' in 1342 , was predominantly of coppersmiths and allied trades (ed. Harding and Wright 1995, 34-35; Salzman 1967, 432). In Bristol, the 'Cokyn Rewe' was occupied principally by cooks (ed. Bickley I900, 2, I33). In Chester the term 'row' may have been applied for similar reasons (Keene in lit.). However the name was also applied by contemporaries to a range of houses which had been constructed as a single structural unit; Lady Row in York, built as such c. I 316 , was certainly known as 'Lady Rowe' by 1548 and was in I 585 described as 'one frame called the Lady Rowe' (Short 1980, 9 I for references). In some instances the two explanations are indivisible, as for instance in the Butchers' Row at Shrewsbury, built in 1458 for the abbot of Lilleshall (Moran I994, 32-35). At Chester the term could also have been applied by contemporaries struck by the common adoption of a particular form of split 
level planning to enable commercial use on two storeys (Harris 1994). Uniform rows of houses built for primarily domestic purposes and for letting were more commonly called rents. In I335 a range to be built in Coney Street, York, was referred to as 'septem domos rentales' (Salzman 1967, 430). The term 'rent' continued to be used until the nineteenth century (Keene in lit.).

The analysis of post-Great Fire house plans has also provided grounds for further inquiry into the links between medieval and post-medieval practice. Kelsall (1974) examined the plans of these later seventeenth-century town houses in greater detail, his purpose 'to demonstrate a form of small house plan which appears to be common in the period 1660 to 1680 , and which differs from the typical plan of later years' (ibid., 80). His conclusions included that the post 1680 plan, with the staircase placed at the rear rather than in the centre, was 'more economical in both space and materials ... attractive to the cost conscious speculator'. The question of the origins of the earlier plan, with centrally placed staircase, was more complex, but developments in other towns as early as the late sixteenth century indicated that it was perhaps incorrect to see the houses of I660-80 'only as precursors of Georgian London'; the answer would have been found in 'the now missing examples of urban vernacular architecture in seventeenth-century London' (ibid., 88-89).

Moreover, since the publication of Kelsall's paper more information on the town house in London before the Fire has been supplied in profusion through the work of Schofield $(1984 ; 1987 ; 1989 ; 1994)$. The smaller houses to be found in London in the late sixteenth and early seventeenth centuries fell into two main categories. The first was the 'type I' house, the plan allowing for one room upon each floor, a plan type previously noted in Norwich, King's Lynn and Great Yarmouth. The second was the 'type 2' house, two rooms on each floor and similar to those recorded by Pantin in Oxford and in Exeter (Schofield 1989, 122-32; it should be noted though that no. 126 High Street, Oxford, was built as one room deep, see Munby et al., 1974). The greater part of this information comes from early seventeenth-century plans, notably those by Ralph Treswell. These do not though provide many insights into the houses being built in London in the late sixteenth and early seventeenth centuries. Essentially, they contain information on the plans and uses of rooms of houses extant in c. 16I2; only very occasionally are there associated documents to indicate when these houses were built or how they functioned when first built. Houses which appear to have been new built at attested dates are nos. 23-25 Abchurch Lane of $c$. I 390 (Schofield 1989, I00-03), nos. 62-63 Mark Lane of I 562-63 (ibid., 92) and no. 46 Blackman Street of c. I 585 (ibid., I 38). A good number of the houses shown on Treswell's plans may have been one or several centuries old, many the outcome of continuous processes of adaptation, when surveyed by Treswell and others.

\section{THE NEW BUILT TOWN HOUSE IN LATE SIXTEENTH- AND EARLY SEVENTEENTH-CENTURY LONDON}

The main part of this study is therefore directed at establishing the form and context of the new built town house in late sixteenth-and early seventeenth-century London, to ascertain whether the origins of the later seventeenth-century and Georgian town 
house lie only in Inigo Jones's and ensuing developments, or whether these were part of a continuum of building traditions extending back into the sixteenth and possibly earlier centuries.

The developments of the I630s onwards, of Covent Garden, of Lincoln's Inn Fields, etc., have been rightly stated to be architecturally the start of a new tradition, associated with the adoption of the Palladian style in the context of large-scale high status urban developments. In this inquiry we are concerned with the middling and artisans' houses. In looking for the precursors of the very large numbers of houses of this type built after the Fire, we must ask whether there were developments other than Covent Garden and its successors, which may also have played a part in informing the experiences of the post-Fire developers. Kelsall's questions concerning the development of the small house plan characteristic of the period 1660 to 1680 , but found in other towns from the late sixteenth century, might also be addressed to the larger body of information now available. We may also re-examine the date at which brick built new streets first emerged on the urban landscape of London, and the extent to which the relationship between amenity, improvement and rental values was already present in the consciousness of property developers before the 1630 .

An important body of evidence, not previously considered in any such inquiry, is that relating to the former fairground to the north of Saint Bartholomew's Priory. The potential of the documentary evidence was highlighted in Webb's study of the priory precinct (192I). The survey by Gilbert Thacker of Sir Henry Rich's estate dated November I6I6 includes details of leases, the numbers of tenements, the names of rooms, the lessees and tenants and much other information ( $\left.\mathrm{PRO} \mathrm{SCr} 2 / \mathrm{I}_{1} / 39\right)$. This information is supplemented by many of the leases abstracted in a survey of 1621 (PRO SCI2/I/22). There is also much useful information on early photographs and prints, in the Royal Commission on Historical Monuments inventory for the City of London (1929), and in the record files for the latter, now in the National Monuments Record. Work on the Royal Commission inventory evidently commenced in I9II and was renewed in 1928. The principal investigators, Clapham in I9I I and Phillips in 1928 , were concerned only with the recording of the buildings, and not with linking this information to the material utilized in Webb's historical research. From these sources has been constructed a summary list of the houses constructed between I 597-I6I 6 (see Appendix 3). Fieldwork undertaken in conjunction with this work has led to the identification of several surviving houses of this development.

\section{ST BARTHOLOMEW'S FAIR ON THE EVE OF REDEVELOPMENT}

One of the largest single new housing developments of the late sixteenth or early seventeenth centuries in London was that undertaken in the fairground of the priory of St Bartholomew. One of the greater fairs of medieval England, St Bartholomew's Fair was by the seventeenth century held for seven days each year, on the three days before, the day and the three days after the feast of St Bartholomew, on 24 August (PRO E2 I4/75 and other leases). By the late sixteenth century this ground was known generally as the Cloth Fair. 
LONG LANE

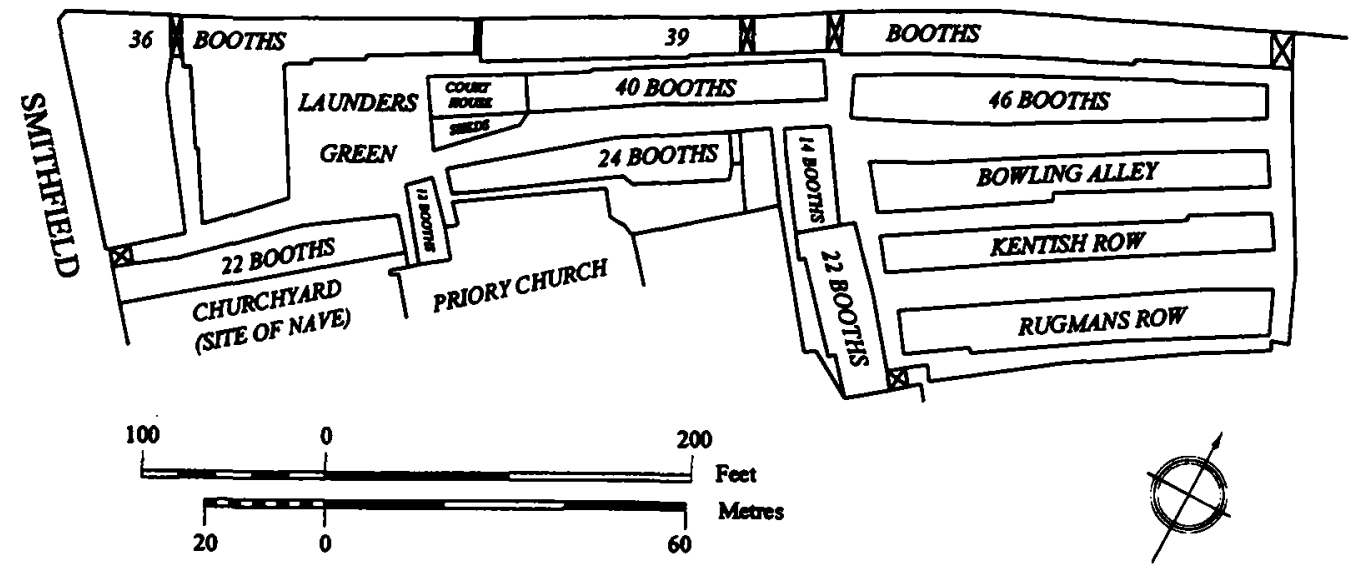

Illus. I. St Bartholomew's Fair, showing the location of the rows of booths by $c$. I 595

By the late sixteenth century the fair was configured around rows of booths, aligned on the axes of both the former priory church and the precinct boundary walls (Illus. I). Immediately north of the demolished priory nave was a row of 22 booths, and to its east a row of $\mathrm{I} 2$ booths on the site of the north transept and said to be in Ladies Green (for references to the documentary sources here and in the succeeding sections see Appendix 3). A further row of 22 booths was built up against the north wall of the choir; on the east and at right angles were a further two rows, one of 14 booths extending northwards, the other of 22 booths situated to the east of the Lady Chapel, extending south to the gate into the monastic close. To the north of the priory church were 36 booths, some fronting Long Lane and some in two rows of booths on Launders Green; the pump situated here by 1614 was possibly a feature of the this green, and the associated activities an explanation for its name. Further east and north of the Choir in Ladies Green was a row of 24 booths, to the north of which was the Court House, used for the Pie Powder Court to deal with the numerous trading disputes at the time of the fair. Against the court house were at least eight booths 'shedwise'; extending eastwards from it was a row of 42 booths known as the 'Long Tyle House', presumably a unitary structure under a single roof. To the north and against the precinct wall alongside Long Lane were a further 39 booths, extending from the Court House and the row of 36 on the west to the east side of the fairground. In the eastern part of the fairground were a further four rows of booths, the northernmost of 46 booths, probably 23 on each side of the row. To the south were three rows of similar length, the northernmost known as the Bowling Alley, the two to the south later known as Kentish and Rugman's Rows. The fairground on the eve of its redevelopment for housing must therefore have contained a minimum of $c .400$ booths.

There are clear indications that the structures within these rows were permanent and used from one year to the next. The 'Long Tyled House' was one such structure. A lease for the redevelopment of 14 of the 22 booths east of the Lady Chapel allowed for the reuse of the building timber. The booths appear to have been numbered; 
immediately inside the north wall of the precinct the easternmost two booths were in I 598 known 'by the name of thirty eight and thirty nyne boothes'. The booths also varied in size. The larger booths would have included the 'double boothes' in the row known as the Bowling Alley, and the 39 booths 'leading upon the north stone wall', replaced in the redevelopment by a roughly similar number of houses. Unlike the later houses, this row of booths fronted only southwards. The smallest booths must have included those in the rows of 42 and 46 , replaced by $\mathrm{r}_{4}$ and $\mathrm{I} 7$ houses respectively; from the evidence for the redevelopment of the latter as Kelshawe's Row, it is clear that one set of 23 booths would have faced north, the other south. In the Bowling Alley row immediately to the south, the double booths were possibly of the same arrangement, booths facing opposite ways simply combined for a single lessee. Booths were able to face both ways from a single row because of the access routes provided through the fair. These can be identified through many having survived the redevelopment to become new streets or passages. For instance, the pre-redevelopment access to both sides of Long Tyled Row, the row north of the choir and the row east of the Lady Chapel, is clearly evident from the Ordnance Survey plan of I 873. Other former access routes through the fair are identifiable through being later incorporated within the curtilages of new tenements, but at the same time being within an area excluded from the lease for redevelopment, as on the south side of the Bowling Alley row. An archaeological watching brief in the Cloth Fair provided evidence for gravel surfaces (Bentley 1984), but to contemporaries some at least of the fair was grass, as in Launders and Ladies Greens.

\section{THE REDEVELOPMENT OF ST BARTHOLOMEW'S FAIR}

Analysis of the redevelopment of the fair is presented with problems in the survival of sources. The leases for the period of rebuilding and development are known only through their being summarized in the survey of 1620 (PRO SC $12 / 1 / 22)$. The earliest lease so far traced is of $\mathrm{I}_{3} 0$ (PRO E2 $\mathrm{I}_{4} / 6$ ). Until any surviving earlier leases are traced some details are unavailable to us, such as the terms under which plots and booths were formerly held and/or under which tenants were obliged to repair or rebuild.

The redevelopment of the fair proceeded in three main phases, each involving the replacement of the existing rows of booths with rows of new houses (Illus. 2). The first phase of this process seems to have commenced in I 597, with at least half of the leases for the part of Cloth Fair on the north side of the former priory nave being regranted at that date. Many more leases were granted in the next year, some 17 on March 26 th. The remaining rows closest to the church, and some of those to the north, were all redeveloped from this date. The evidence for this can be briefly summarized (for details and references see Appendix 3). On the site of the north transept the 14 booths leased to Edward Holmes in I 598 were by 1616 the three houses known as Holmes's Buildings. To the east the 22 booths against the north side of the Choir and Lady Chapel were by I6I 6 the 12 tenements in the Old Gallery. To the north, eight of the twelve leases recorded in 1616 for the south side of Long Lane were issued between February and April I 598 . In I 598 this was the row of 39 booths extending eastwards 


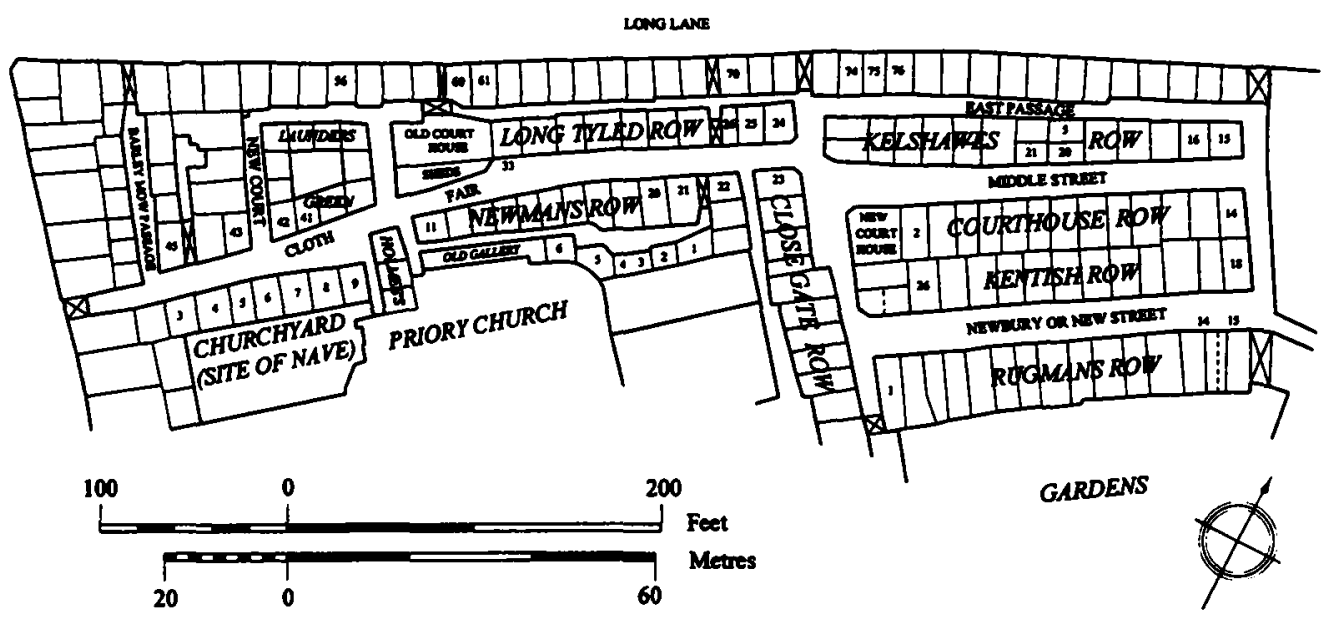

Illus. 2. The redevelopment of St Bartholomew's Fair by c. I6I6

from the old Courthouse; by 1616 there were 36 houses. The redevelopment is most likely to have commenced in 1598 , with the large scale reissuing of leases.

Some of the rebuilding can be more closely dated. In Newman's Row, replacing the row of 24 in Ladies Green, three of the five leases recorded in 1616 were granted in 1598 (on $26 \mathrm{March}$ ), while a fourth, recorded as being granted in I $58 \mathrm{I}$ to Matthew Wilkinson, had been partly regranted in December 1599 , for 'a new frame' (which can be identified as no. 21 Cloth Fair), erected between a house to the west (no. 20, which was also leased to Wilkinson) and one to the east (which can be identified as no. 22 Cloth Fair). Several houses to the west was a plot of ground, precisely measured and not of booths, leased to Robert Threader in I598. It is clear that houses in Newman's Row and Harthorne Row (incorporating no. 22) were completed or being built within two years of the large-scale regranting of leases. In Kelshawe's Row, a tenement granted to Richard Thorne in 1600 was 'lately built' (PRO SC $12 / 1 / 22$ fol. 3).

Within these rows, the leases for some properties were not regranted in I 598 , their holders possibly preferring at that stage not to enter into whatever more detailed arrangements for rebuilding may lie behind the many leases granted in I 597 and I 598 . In the Long Tyled Row (in 1598 the row of 42 booths), six booths to the south of the Old Courthouse certainly remained until at least 1604 , a new lease of them being given then to Richard Toppin (PRO SC $12 / 1 / 22$ fol. 6).

Only one lease granted in I 598 shows explicitly that rebuilding was intended. To the east of the Lady Chapel was the row of 22 booths, replaced by I6I6 with the ten tenements in Close Gate Row. Part of the row had been leased to Richard Toppin in I 598, his lease inclding 'the building timber over the said I 4 boothes' (PRO SCI2/I/ 22 fol. 5). Nevertheless, from both the large-scale regranting of leases in I 598 and the evidence for some fairly immediate rebuilding, it is clear that the almost complete transformation of the fair commenced on a large scale in 1598 , with the deliberate redevelopment of the rows closest to and north of the church. 
By the beginning of the seventeenth century, the fair was thus part redeveloped, part still rows of booths. The replacement of the remaining rows seems to have commenced in 1605 with the building of a new court house more central to the fair, at the west end of Courthouse Row, in what was later to be Middle Street. Redevelopment proceeded slowly. The next plot to the east, part of a double booth adjoining to the court house, and seven and a half double booths to the east, was leased to William Cossen in 1608. The eastern plot was still largely covered with booths when leased to Henry Hayward in 16I2. In this lease only the land later occupied by the actual houses was granted to Hayward. The land to the south was still presumably the means of access to the north side of the booths in the row to the south, later Kentish Row.

A second area in which redevelopment started during these years was the west part of Launders Green. Here the lease granted in 1609 to Thomas Rogers was of both his dwelling house, with four booths, a pump and a vault, and of two rows of booths in Launders Green. This property can be identified as the block of houses on the north side of the Cloth Fair, bounded on the east and west by New Court and Barleymow Passage respectively. By I6I6 the two rows of booths had been replaced by three houses fronting Cloth Fair (PRO SCI $2 / 1 / 22$ fols. 4-6).

Redevelopment of the remaining rows proceeded much more rapidly from I6I 3 . The 1616 survey records five leases for the 15 houses in Kentish Row, five granted in I613, one in January 16I4. That all the leases should be granted in the space of one year indicates that development of the row commenced at that date. It was certainly complete by I 6 I 6 when I 5 tenements were recorded.

The final stage of redevelopment commenced with the granting of I I leases on the feast of St Bartholomew, the central day of the yearly fair (the leases are dated to November and December of the same year, but noted in the survey as granted at 'Bartholomew Tyde'). These comprised all but one of the six leases listed in 1616 for 'the II houses upon the square in Launders Greene' and all but one of the seven leases listed for Rugman's Row (one having been granted in June 16I4).

The II houses in Launders Green can be identified as the block of houses on the north side of the Cloth Fair, bounded on the east and west by New Court and Sun Court respectively, on the north by the lane running between the two. The leases granted in I6I 4 give the measurements of most of the plots and enable the individual tenancies to be identified. One house was larger than the rest, being in 1616 'two tenements arranged as one new built of brick', held by William Chapman. The seven leases for the I 5 houses in Rugman's Row were all of parcels of ground, five of them said to be abutting 'boothes' on one or both sides. For instance, the $66 \mathrm{ft}(20.12 \mathrm{~m})$ long plot leased to Christopher Jordan was said to abut west on the 'boothes' of John Wyster; Wyster's lease of the same date referred to Jordan's 'boothes' on the east (PRO SCI $2 / 1 / 22$ fols. I-2). By I6I6 there were Is tenements, all 'uniformally built with bricke'.

By I6I 6 the redevelopment of the fairground was complete. Some 400 or more booths had been replaced by $c$. I 75 houses, possibly the largest single development scheme in London in the three centuries preceding the development of Covent Garden. Before tuming to more general questions relating to those involved and their 
motives, we must ask why this undertaking merited no mention in the play set within its confines.

\section{'AS DIRTY AS SMITHFIELD, AND STINKING EVERY WHIT'}

The special circumstances surrounding the rows built in one of England's largest medieval fairs certainly require further comment. Much of this can come direct from the words of Ben Jonson whose drama 'Bartholomew Fair' was probably completed in I6I 4 (ed. Hibbard I977). The redevelopment of the fair was by then largely finished, most of the remainder in hand. Yet, from Jonson's play we taste only the flavour of the medieval fair, not a hint of the housing redevelopment that had commenced in the late I 590 s.

Jonson had observed in Bartholomew Fair 'a special decorum, the place being as dirty as Smithfield, and stinking every whit'. His character Busy thinks 'the whole Fair is the shop of Satan! They are hooks and baits . . . hung out on every side to catch you ... you must not look, nor turn'. The eyes of the crowds could be transfixed by such attractions as the 'great hog' and 'the bull with five legs ... and two pizzles' (ibid.). The principal structures within the fair are booths. Littlewhit proclaims 'we'll seek out the homliest booth i'the Fair'; Ursla admonishes Justice Overdo that 'you look as though you had been i'the corner o' the booth, fleaing your breech with a candle's end, and set fire o' the Fair'. Mooncalf asks of Master Knockem that 'For the honour of our booth, none o' your vapours here' (ibid.). The accounts for a I6I 4 performance show that payment was made to cover costs including 'canvas for the Boothes' (ibid., $\mathrm{xv})$. The approximate date of Jonson's play is fixed by its first performance and form of printing. We must ask why Jonson made no mention of the substantial numbers of new houses within the fair, and not even in passing mentioned its recent and contemporary redevelopment. The answer is probably at least twofold.

First, as has been demonstrated above, the new houses of the I 590 s and onwards were built within the existing fabric of the fair. Secondly, the ground floors of the new houses continued to be given over annually to the uses of the fair. Well into the seventeenth century new leases of properties in St Bartholomew's Fair continued to reserve out of them rights for the period of the fair. Typical is a lease of 1645 to Millicent Smyth victualler of a property in Launders Green, probably nos. 4I-42, consisting of one cellar, two lower rooms, four chambers and two garrets, reserving out of the lease the use of the two lower rooms for the space of seven days centred on St Bartholomew's Day (PRO E214/75). To those attending, these lower rooms, given over entirely to the traditional uses of the fair, may have continued to be perceived as 'boothes.' The occupants of the Launders Green houses were, as the I6I6 survey noted, privileged to have an independent access from the central courtyard into their houses at fair time, 'an entry for all the tennants to come into their houses in the faire

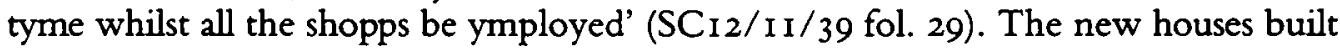
in St Bartholomew's Fair were therefore provided with a dual identity. Jonson was concerned only with that of the fair. For him at least, its attractions were such that it was irrelevant to look upwards or beyond. The extent to which the tenants themselves were immersed in the fair would be a separate subject of research. 


\section{DEVELOPER AND SPECULATOR}

The priory of St Bartholomew had been granted to the first Lord Rich at the Dissolution. It was the third Lord Rich, inheriting the estate in I581, who was responsible for issuing the leases under which redevelopment proceeded. It was possibly judged that the income from the yearly rents of substantial tenements would be greater than from the booths of the seven day fair, particularly when the ground floors of the new houses were still at his disposal for letting during the fair. It is clear from rentals of the seventeenth century that these hopes were more than realized, with rents being rapidly increased beyond those initially set (PRO SC/12/40/65-67; this aspect of the redevelopment has not been studied in detail). We would be wrong though to place Rich in Summerson's category of 'noble speculator'. The redevelopment of St Bartholomew's Fairground was undertaken piecemeal, by many individual developers, the overall plan determined by that of the preceding fair.

The occupations of the individual developers are not given in either the survey of 1616 or the abstracted leases of $162 \mathrm{I}$. Richard Thorne took the greatest number of leases. He, with a few other individuals such as Richard Toppin (four leases) and Thomas Rogers (four leases) is likely to have played a major role in the redevelopment. Both, Toppin and Rogers were notable for selecting the larger and already existing houses for their own residences. Richard Toppin took the old court house as his dwelling. Thomas Rogers's house was a substantial and probably older set of buildings on the north-west side of Launders Green. It would be of interest to know how they and other lessees related to the building craftsman milieu of early seventeenth-century London.

\section{THE HOUSES OF CRAFTSMEN AND SHOPKEEPERS}

From the numerous plans of houses existing in early seventeenth-century London, it has been shown that the smallest were of one room on each floor (Schofield, op. cit.). In the redevelopment of St Bartholomew's Fair we are given abundant confirmation that in the late sixteenth and early seventeenth centuries the house of one room on each floor was the preferred plan for the new houses of craftsmen and shopkeepers. The I6I6 survey provides the details of only is of the tenants' occupations; within this small sample tailors were the most numerous occupational group. All but one of the tenants of the new houses were craftsmen or shopkeepers. The survey shows also that, with a few exceptions, the houses of the St Bartholomew's Fair redevelopment were of uniform plan, of three storeys and an attic, of one room on each fioor. Each house was provided with a cellar, a shop on the ground floor, a single chamber on each of the first and second floors above, and a garret in the roof. Of the 175 houses built between 1598 and 1616 , at least 140 conformed to this design.

The detailed workings of this plan can be seen in several recorded and surviving examples. No. 25 Cloth Fair was recorded in plan, section and elevation (CLRO 96.D.1I) by Guy W. Haywood, architect, in 1908 (Illus. 3; for photograph see Illus. I4); these records were probably made prior to its demolition, since it was not amongst the houses recorded by Clapham in 191 I. Each floor was jettied, so that the upper rooms were progressively larger than those below. The ground-floor plan 


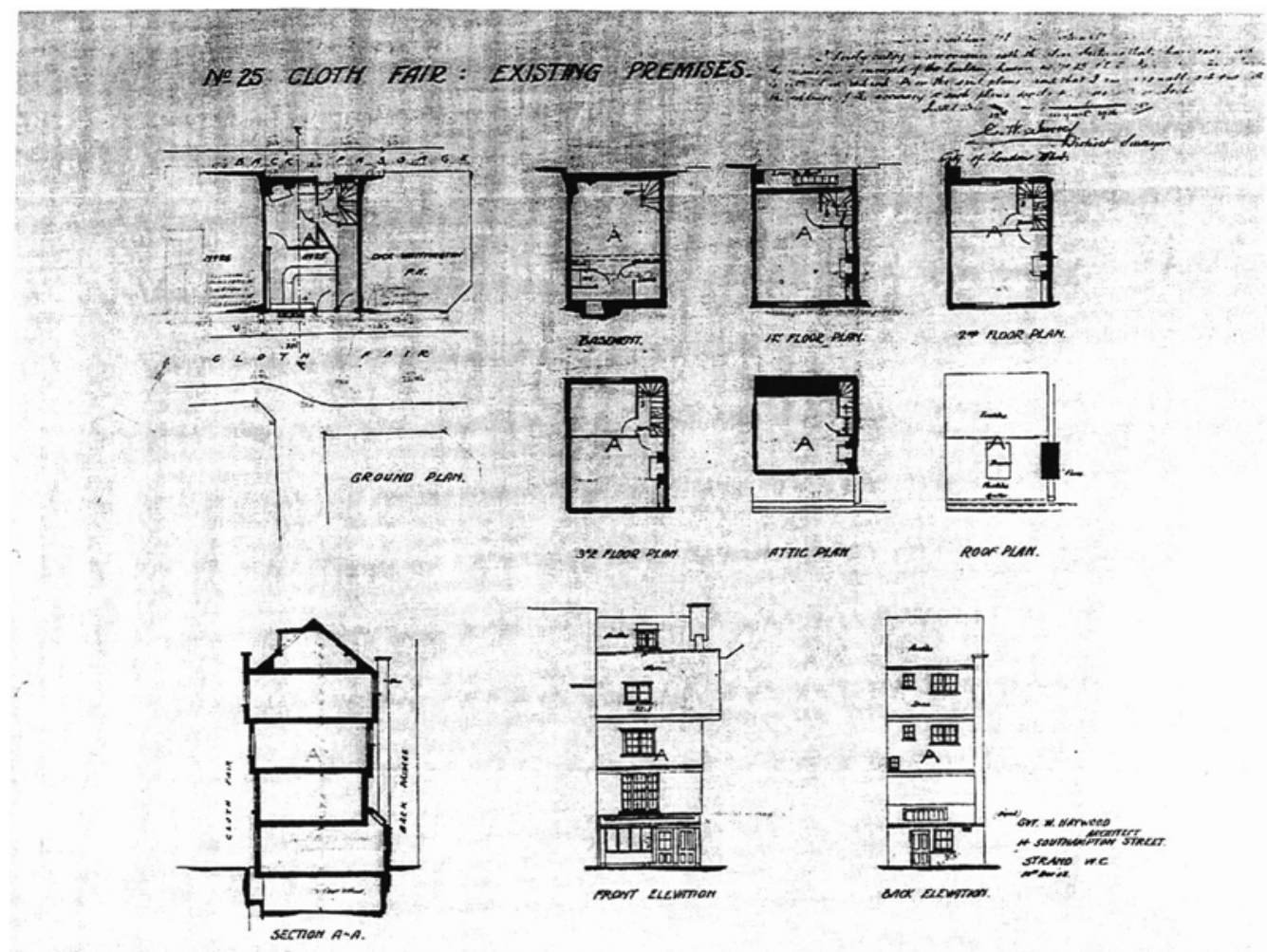

Illus. 3. No. 25 Cloth Fair, built $c$. I 598 , plan, section and elevation by Guy W. Haywood, architect, I908, copyright City of London Record Office

allowed for access both from the Cloth Fair, and from the passage to the rear. The stairs were placed adjacent to the back door, which would have provided the occupants with a more private access to the upper floors at fair time. The winder and part framed stairs evidently rose through the full height of the cellar, four storeys and attic. The chimney stack was in the party wall with no. 24; by 1908 there was a fireplace on each floor, apart from the cellar. This house can be identified in the 1616 survey as the second of the first four houses in Long Tyled Row, leased to John Robinson of the Cardmakers' Hall, Holborne. These were built on the plot formerly occupied by 14 booths, leased to Humfrey Haley in I 598. Each contained 'a cellar, shop, 2 chambers and a garret'. The plan at first-floor level of no. 25 was probably the original arrangement, a single heated chamber and the enclosed stairs occupying the entire floor.

On the opposite side of Cloth Fair were the three houses constructed as Harthorne Row in I 598/99. In I6I6 the northernmost (no. 22 Cloth Fair) and the centre house each consisted of a cellar, a shop, two chambers, and a garret. By I 886 the centre house of the row of three was joined to no. 22 (Goad I 886). Together with no. 22, this house was recorded by Clapham in $191 \mathrm{I}$; drawings of the elevations were also made 

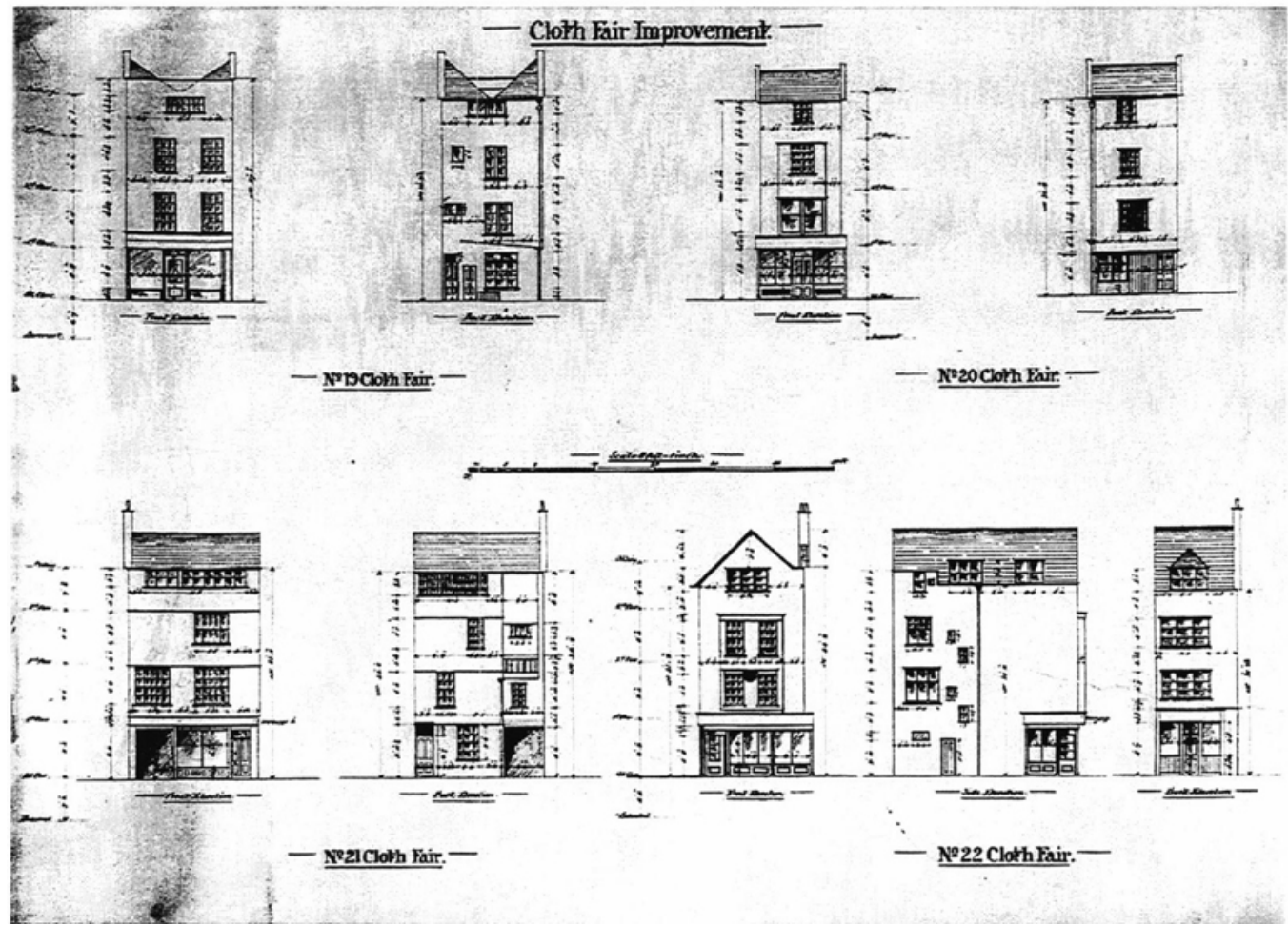

Illus. 4. Nos. 19-22 Cloth Fair, elevations, copyright City of London Record Office

on behalf of the City of London prior to its demolition in I9I7 (CLRO 96.D.3). These records show that it was of similar plan to no. 25 Cloth Fair. The principal elevation and main access were to the alley on the west. A sketch plan by Clapham shows the precise position of the stairs and lobby; this had 'one newel continuous the other with balls and drops, as well as tumed balusters of $c$. 1670'. As in no. 25 , the stairs were adjacent to the rear access on the east side facing Red Lion Passage. This passage was also the rear access for the houses in Close Gate Row or King Street. The side elevation showed pairs of windows lighting the stairs, the smaller ones possibly the original arrangement (Illus. 4).

The same relationship between front and rear entrances, and access to the upper floors is seen in the plan of no. 74 Long Lane. This house is arguably the most complete survivor of the original development of $c$. I 598 onwards, being of similar proportions to the recorded and demolished examples already discussed, being jettied at the first floor and internally having exposed ceiling cross beams (Illus. 5 and 6; extraordinarily, the list of Listed Buildings refers to this house as being of the eighteenth century, its inclusion in the list being solely on account of the mathematical tile cladding). The principal elevation is to Long Lane, the rear elevation facing a narrow alley behind. The entrance to this rear alley is adjacent to the stair. These are placed in the southeast corner, and are of the early eighteenth century; they must replace an earlier stairs, 
possibly in the same position. There are indications of a stack on the west side wall, forward of the cross beam, a different arrangement to that recorded at no. 25 Cloth Fair.

Open at the front and rear, these houses of one room on each floor were well lit. For a number of houses this is clear from the evidence surviving for the early fenestration on both front and rear elevations. The houses backing on to the churchyard, probably built $c$. I 597 onwards, were particularly weil lit, having bay windows to the upper chambers on the Cloth Fair elevation (Illus. 7) and large mullioned and transomed windows to the rear (Webb I92 I pl. XXI).

In the more tightly confined rows it was important that the upper chambers were well lit from the rear as well as from the front, particularly if used for crafts requiring a good light. On the east elevation of the centre house behind no. 22 Cloth Fair two original windows remained, each with mullions and transom, one to the first floor of six lights with a cornice over, and one to the second floor of four lights. Two of the smaller windows lighting the stairs and lobbies were also possibly of the original design (Illus. 4).

Although some I 43 houses were built to this one room plan, very little information survives regarding their interior finish. Webb's notes on no. 22 Cloth Fair are principally of value for indicating that much of what remained even to the twentieth century was very much a palimpsest of what had existed. He records that 'the front room on the first floor was panelled to the ceiling with one panelled trabiation across'. In the west wall was 'a handsome arched alcove with two fold doors . . flanked by fluted pilasters c. I700'. The house was demolished in 1917 (Webb 192 I, 238).

The Treswell Plans show many houses of similar plan; the best dated examples are those at nos. 62-63 Mark Lane, built as a row of four houses $c$. I 562-63. These were within one timber-framed structure, each house with the stairs to the upper floor against the rear wall, but differing from most of the St Bartholomew's Fairground houses in having detached two-storey kitchens (Schofield 1987, 92-93).

\section{THE SMALLEST HOUSES}

The smallest houses built in the redevelopment of St Bartholomew's Fair were in Kelshawe's Row, later the north side of Middle Street. Here six tenements were constructed back-to-back so as to occupy half a plot each. Two of these, no. 20 Middle Street and no. 5 East Passage to the rear, were built on the plot occupied by four booths leased to John Sawell in I 598. In I616 one of these two back-to-back houses was in the tenure of two persons (occupations not named), the other of Thomas Warren, brewer. Each was said to be 'in bredth about 9 foote' and 'of like bignes'; the half plots shown on the 1873 map are of this depth. The four remaining back to back houses commenced one plot distant to the west and can be identified as nos. 22-23 Middle Street and the houses behind in East Passage. These were held by a lease granted to Richard Thome in June 1612 , possibly that for the plot lately built with booths and now a woodyard. Facing Middle Street, one was 'but haulf the bredth of the rowe', the adjacent house was 'of like quantitie as the former'. Facing East Passage, a third house was 'half the bredth of the rowe', the house adjacent 'half the bredth as aforesaid'; on Thome's plot only the eastemmost house in the tenure of Hannibal 


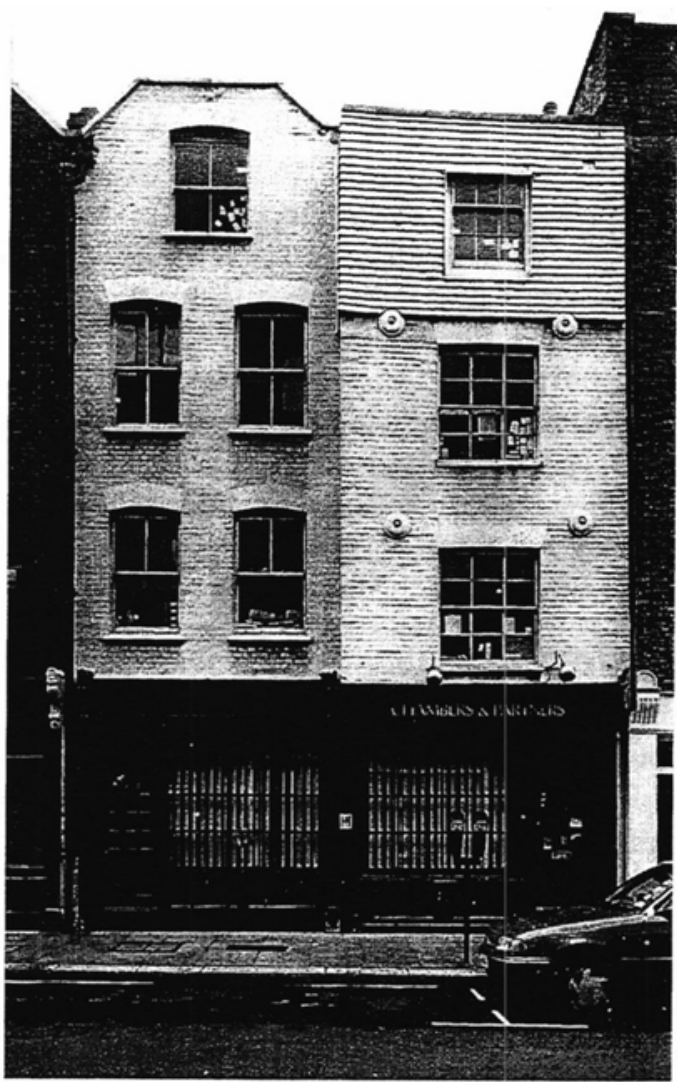

Illus. 5. No. 74 Long Lane, built c. I 598, a surviving house from the original development, jettied at the ground floor and faced in mathematical tiles above. To the left is no. 75 , possibly of the same date but more probably rebuilt later in the seventeenthcentury, ccpyright RCHME
SECTION

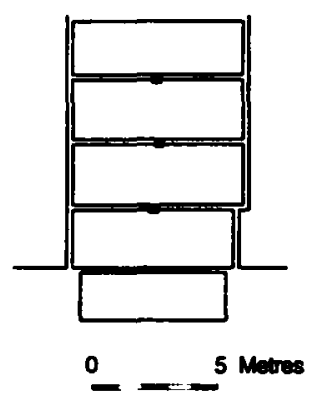

FIRST FLOOR PLAN
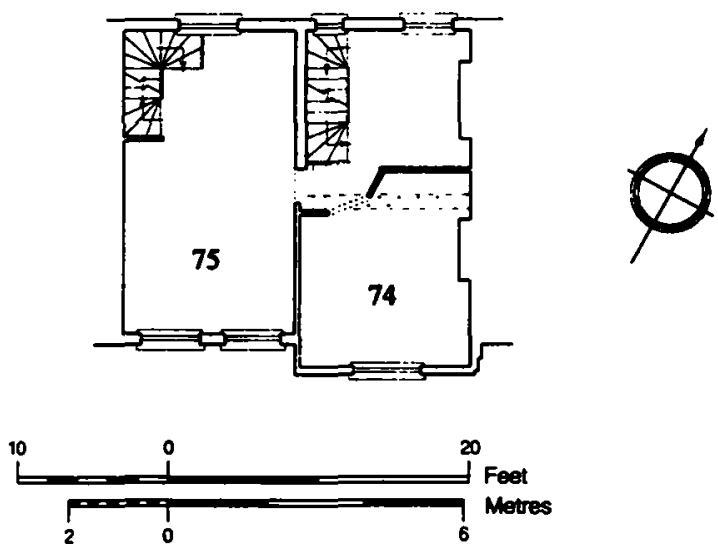

Illus. 6. Nos. 74-75 Long Lane, plan taken from RCHME survey by Peter Guillery, section of no. 74 by Charlotte Bradbeer and Andy Donald, copyright RCHME 
Cesar was 'the whole bredth of the ground'. The disposition of rooms within these smaller houses was as for the houses of one room in depth occupying a complete plot. Each had a cellar, shop, chambers on the two floors above and a garret (PRO SCI2/ I/22; SCI $2 /$ I I/39 fols. I7-I 8).

The two back-to-back houses on the plot leased to Sawell in I 598 were recorded in I 9 I I by Clapham, who concluded that they were built in the late seventeenth century. No. 20 Middle Street and no. 5 East Passage (both since demolished) were built backto-back and were of one build, each with four storeys and a basement (Illus. 7-8; no. 20 was incorrectly noted as no. Io in the RCHM inventory). The positions of the entrances and staircases in each house were shown by Clapham on a sketch plan (RCHME London inventory records). In each the stairs were lit by small windows to the street; the staircase in no. 20 was spiral but modernized.

Knowing now that the houses in Kelshawe's Row were built from c. 1598 onwards, and that six were recorded as constructed as back-to-back in 1616 , we can question Clapham's attribution of the houses to the late seventeenth century. It can be argued that it is improbable that these two very small houses would have been rebuilt in brick in the late seventeenth century (Clapham's conservative dating) to exactly the same back-to-back plan, the same small floor area and the same number of storeys as when first constructed less than a hundred years earlier. From the documentary and architectural evidence (for which see also below) the construction of no. 20 Middle Street and no. 5 East Passage as recorded by Clapham could then be assigned to between 1598 and I616, probably to c. 1612-16 when houses of similar plan on the plots to the west, leased to Richard Thorne, were being built. One of Thorne's houses, no. 6 East Passage, appeared to be of similar brick build. Clapham noted in I9 I I that no. 6 had been modernized, but retained three brick strings or plat bands between the storeys. These are visible on the photograph, which shows nos. 5 and 6 to have been of identical dimensions.

Only six houses of this type were built in the redevelopment by 1616 , from which it might be concluded it was not of great appeal either to speculator or tenant. Apart from the total floor area being less than half that of a house occupying a complete plot, it was not possible in this plan to provide a second access to the upper floors at the time of the fair. It is of interest that the two houses built on the plot leased to Sawell occupied the space formerly occupied by four booths. Possibly there was a structural or tenurial link, at the sub-letting level, between the booths and the later back-toback houses.

\section{DETACHED KITCHENS}

Within the dated developments of the late sixteenth and early seventeenth centuries only two houses in the redevelopment of the rows in St Bartholomew's Fair were provided with detached kitchens. These were located at the west end of Rugman's Row, built c. 1614-16. The two houses held by Thomas Mason in 1616 were each described as containing one cellar, one hall and kitchen, one chamber over the hall, 'one garret over the kitchen', one chamber on the third story and a garret over the same. Schofield has interpreted detached kitchens as 'an older medieval form' (I987, 


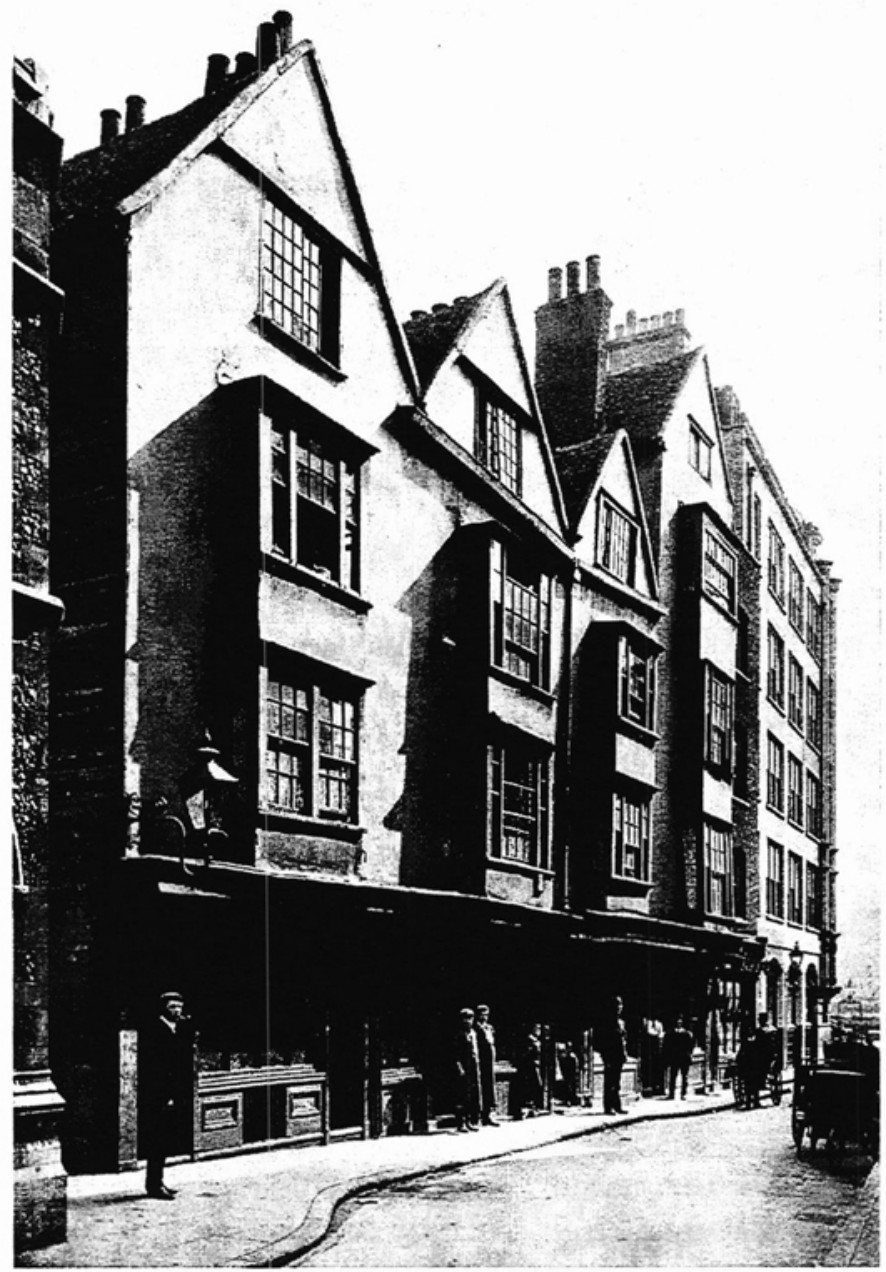

Illus. 7. Nos. 6-9 Cloth Fair, built c. I 598, probably as two pairs of houses, copyright RCHME

I5). More research would be necessary to establish whether this is so in a seventeenthcentury context. Possibly, detached kitchens were regarded as an enhancement to new houses of this period, as in the larger towns of western England, notably Bristol and Exeter (Leech forthcoming; Laithwaite 1995). The detached butteries of nos. I8I-84 Bishopsgate (below) might be seen in a similar context.

\section{BOOTHS AND SHEDS OR SHOPS}

The evidence for the redevelopment of St Bartholomew's Fair provides some new insights into the relationships between booths or sheds on the one hand and the permanent tenements on the other. The term 'booth' was preferred to that of 'shed' 


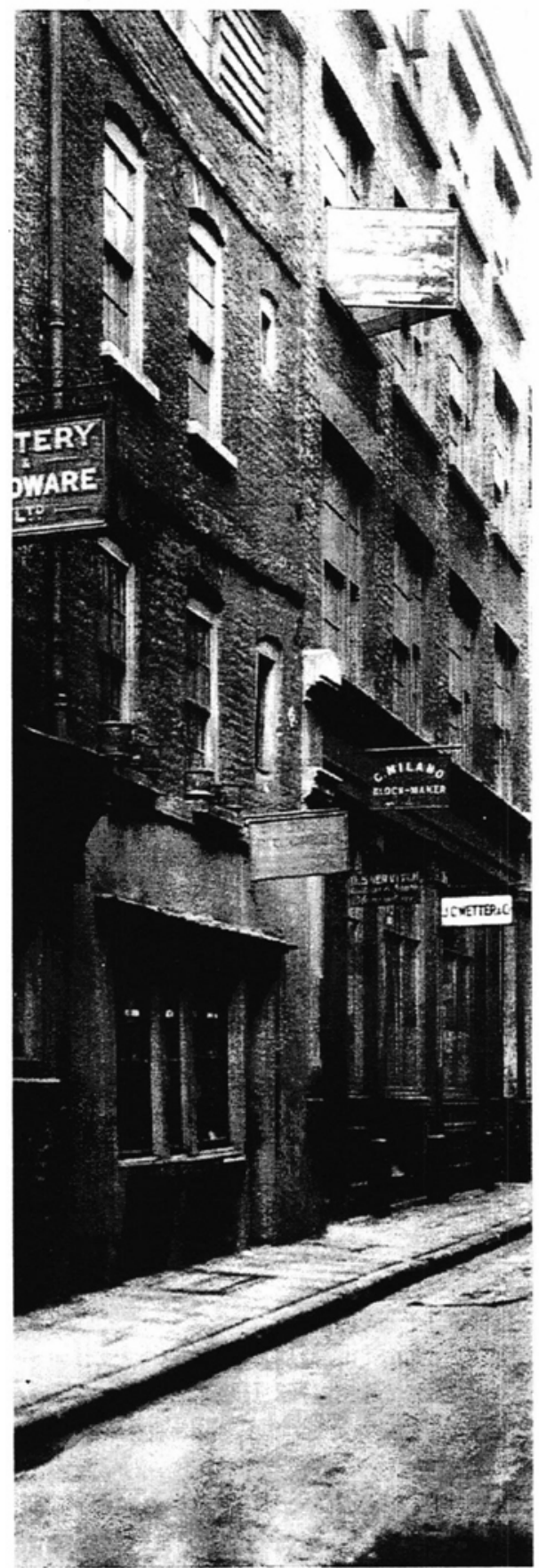

Illus. 8. Nos. 20-2 I Middle Street, of backto-back plan with nos. 5-6 East Passage, built by I 6 I 2 , copyright RCHME

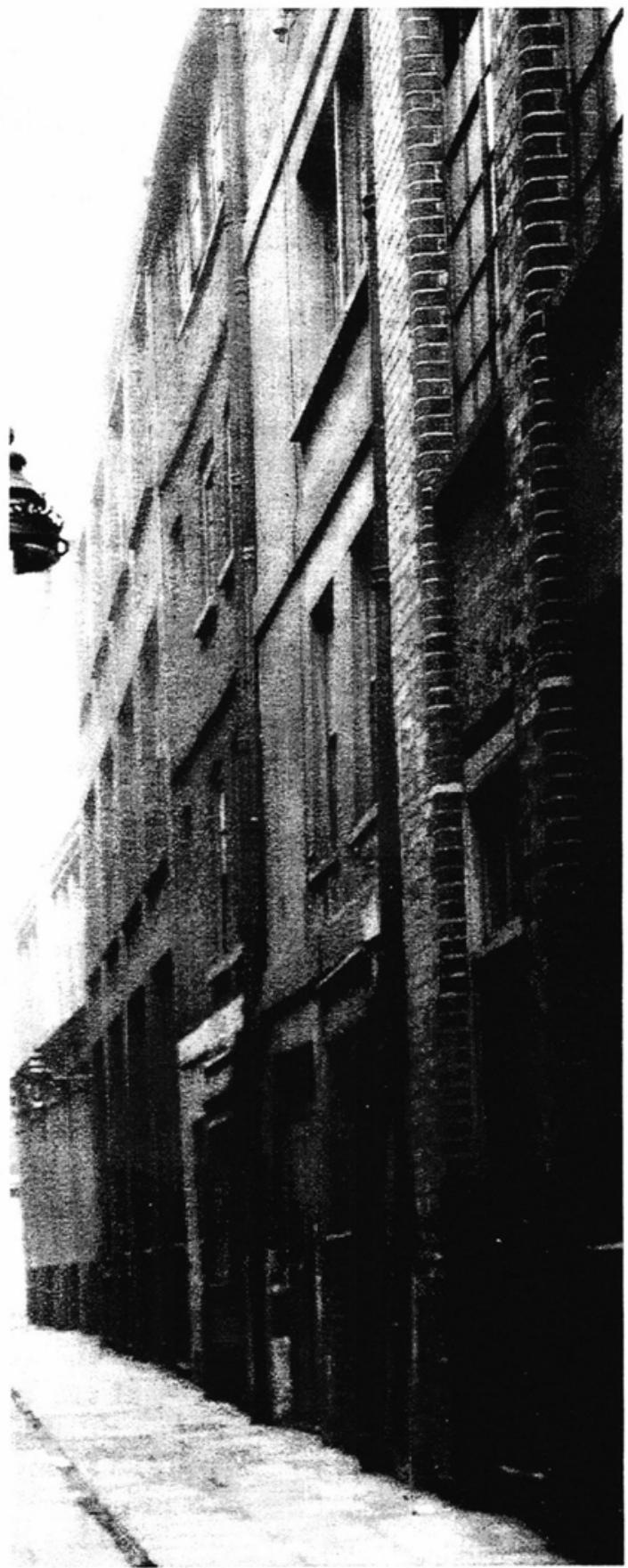

Illus. 9. Nos. 5-6 East Passage, the frames to the ground-floor entrance and the second-floor windows of no. 5 were thought to be of the original build, copyright RCHME 
to describe the individual premises within the fair; that is evident from both Jonson's play and from the leases abstracted in $162 \mathrm{I}$. However it is also clear that these two terms were interchangeable to those familiar with the fair. In a lease of I 593 Robert Rewington took a lease of 'one little shedd or shop ... in length 12 foot and in breadth 5 foot'. The lease to Matthew Wilkinson in I 599 of no. 21 Cloth Fair (above) included also 'one shedd or booth parcell of the row of 22 boothes' under the Old Gallery. A vital clue to what enabled a booth to be a shed comes from other leases. In I 598 Toppin's lease for the old court house included eight booths adjoining 'shedwise' upon the court house; similarly Thorne's lease of 1602 for the west end of the old gallery included $\mathrm{I} 2$ booths adjoining 'shedwise'. We can conclude that a shed was a booth which was built up against another structure $\left(\mathrm{SC}_{12} / 1 / 22\right)$.

This provides an explanation as to why annotations made to the I6I6 survey place such emphasis on sheds, five in Kentish Row, one or two against the Court House in Courthouse Row, two in Launders Green and twelve in Long Lane. These were not structures in back yards akin to modern garden sheds, but were shops on the street frontage, with identifiable rental values to be taken account of in the future issuing of new leases.

An engraving dated 1825 of the 'Hand and Shears' shows two lean-to structures set 'shed-wise' against what was formerly the new court house in Courthouse Row. In the illustration, one of these could be functioning as a shop (Illus. 10). A similar structure was built against the west end of no. I I Cloth Fair, formerly the end house in Newman's Row.

\section{HOUSES OF TWO ROOMS ON EACH FLOOR}

A second house type, Schofield's type two, was quite distinct from those built in such large numbers in the redevelopment of St Bartholomew's Fair. It offered roughly double the amount of space, often more, and double the number of separate living spaces. The plan of two rooms on each fioor is recorded in London from the early fourteenth century. The row of the five houses in Abchurch Lane built $c$. r 390 were of this plan (Schofield 1987, 100-03). These were probably constructed without chimney stacks and thus either unheated or heated by braziers, with winder stairs positioned in the corner, and with detached kitchens; the absence of any chimney stacks on the ground floor indicates that the first-floor chimneys recorded by Treswell were later additions.

By the early seventeenth century such houses could be found principally on the edges of the city, as at 291-99 Borough High Street, Southwark. Here seven houses are shown on a plan of I6II, all of two rooms in depth. In six the stack is placed centrally so as to serve both rooms, the space between stack and side wall utilized for the access between front and rear and for the stairs to the upper floors. In two examples the ground-floor rear room is identified as the kitchen. One of these houses was constructed $c$. I 585 , the building lease from Christ's Hospital specifying that the house was to be of good, strong, substantial and well seasoned oak and of two and a half storeys. The ground floor was to be ro feet $(3.05 \mathrm{~m})$ high, the first floor 8.5 feet $(2.59$ $\mathrm{m}$ ), and the half storey at least 4 feet ( $1.22 \mathrm{~m}$ ) besides the roof (ibid., I 38-39). 


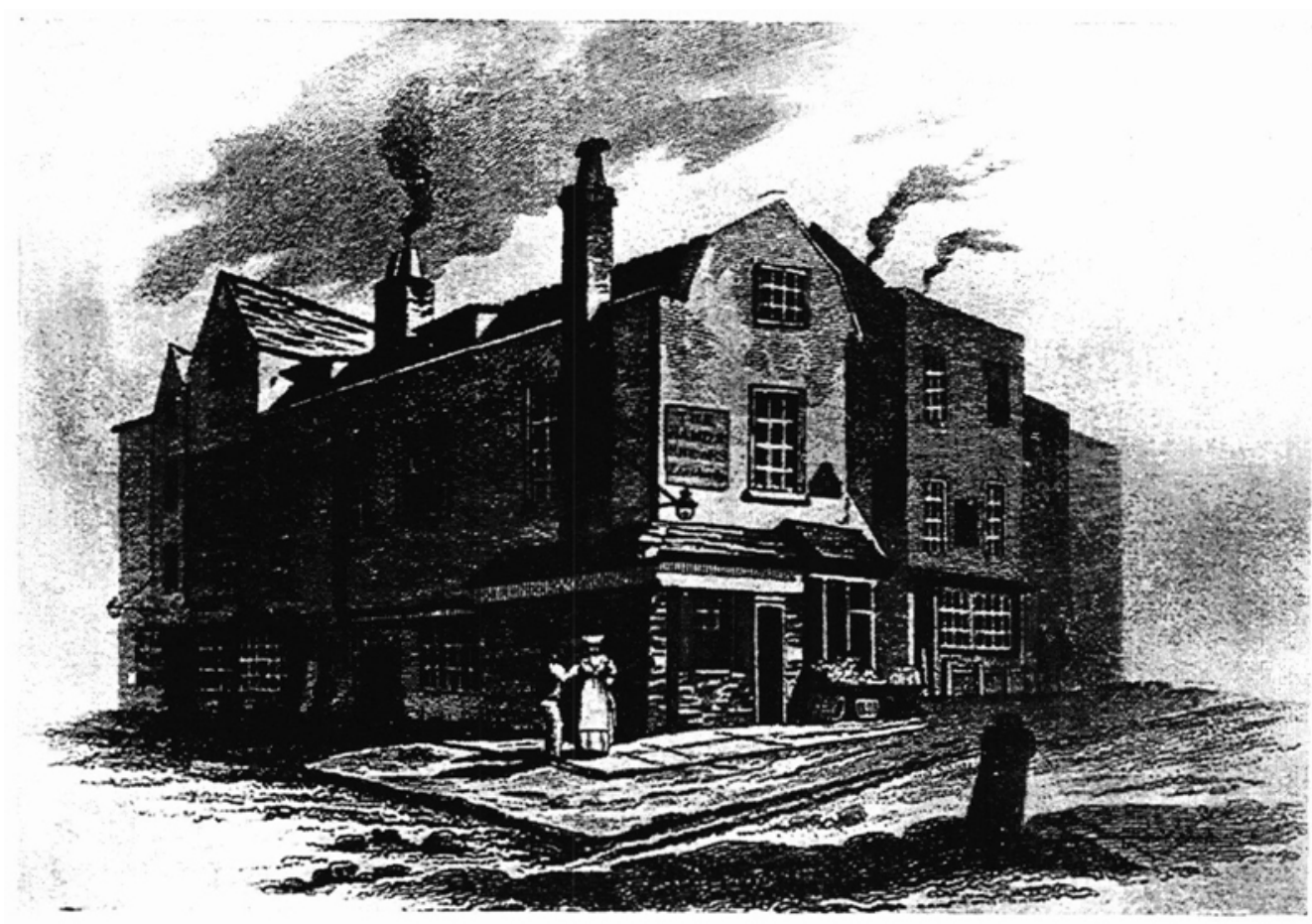

THE " HAND AND SHEARS" (PIEPOWDER COURT;. CLOTH FAIR.

lirin ITikinson's "Londina lliusiruta," 1.82 .7$.

Illus. 10. The new Court House in Courthouse Row, lately built in 1605 , by 1828 'the Hand and Shears'. Note the two booths set 'shedwise' against the west side, and the one room deep gabled houses in Courthouse Row beyond, built I608-16

Four houses in Gray's Inn Lane, built in 1595, formed part of the endowment of the hospital, in Temple Street, Bristol, founded in 1613 by Dr Thomas White of London for love of the Church of God and the poor of the city of Bristol where he was born. The four houses are delineated on a plan of 1822 , contained within one of the plan books of the Bristol Municipal Charities, and published here for the first time; a photograph of 1875 shows the front elevation of the same four houses (Illus. I I-I2). Unusually the plan provides a construction date, through an annotation to the outline of the first-floor jetty of no. 65 , 'a date, I 59 I or I 595 , carved on a wooden bracket figure'; this is confirmed from another source as being I595 (The Builder, June nineteenth 1852, 393; BRO P/StW/Ch/1a; Manchee I831, vol. I, II5-17). The four houses were clearly originally of similar plan, of two rooms in depth, each accessed from a side passage running from the street in front to the yard behind. The front and rear rooms were heated and separated one from the other by a centrally placed chimney stack, against which was placed a closet for each room and the stairs to the floors above. The plan of no. 65 is probably the least altered from the original 


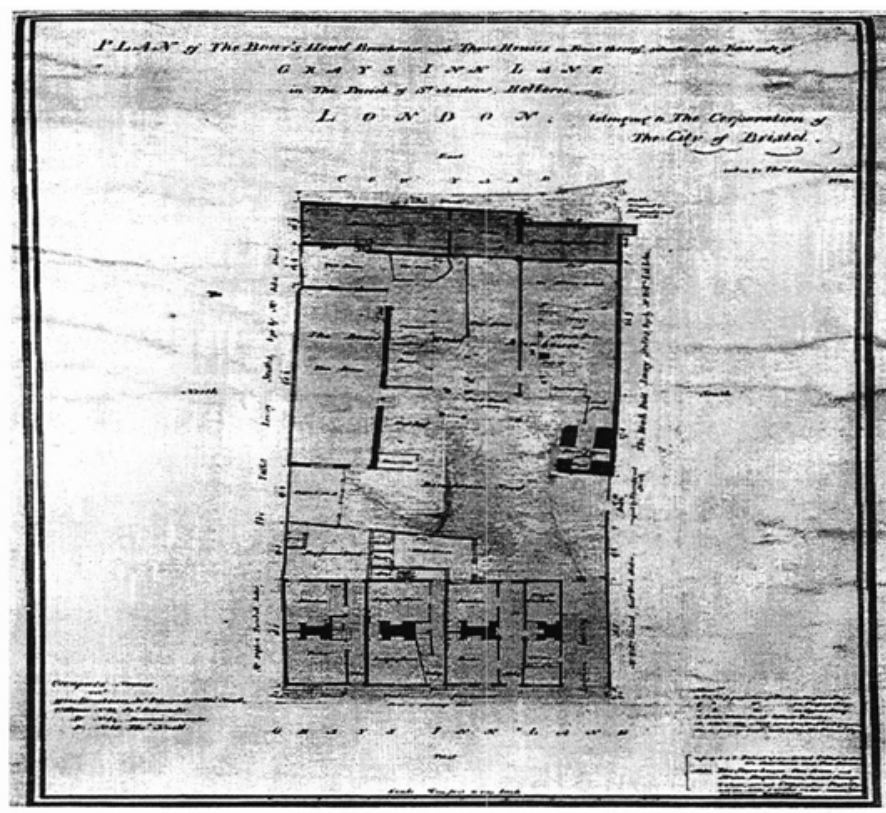

Illus. II. Nos. 63-65 Gray's Inn Lane, built 1595 , plan of I822, copyright Bristol Record Office

Illus. 12. Nos. 61-65 Gray's Inn Lane, photograph of 1875 , copyright RCHME

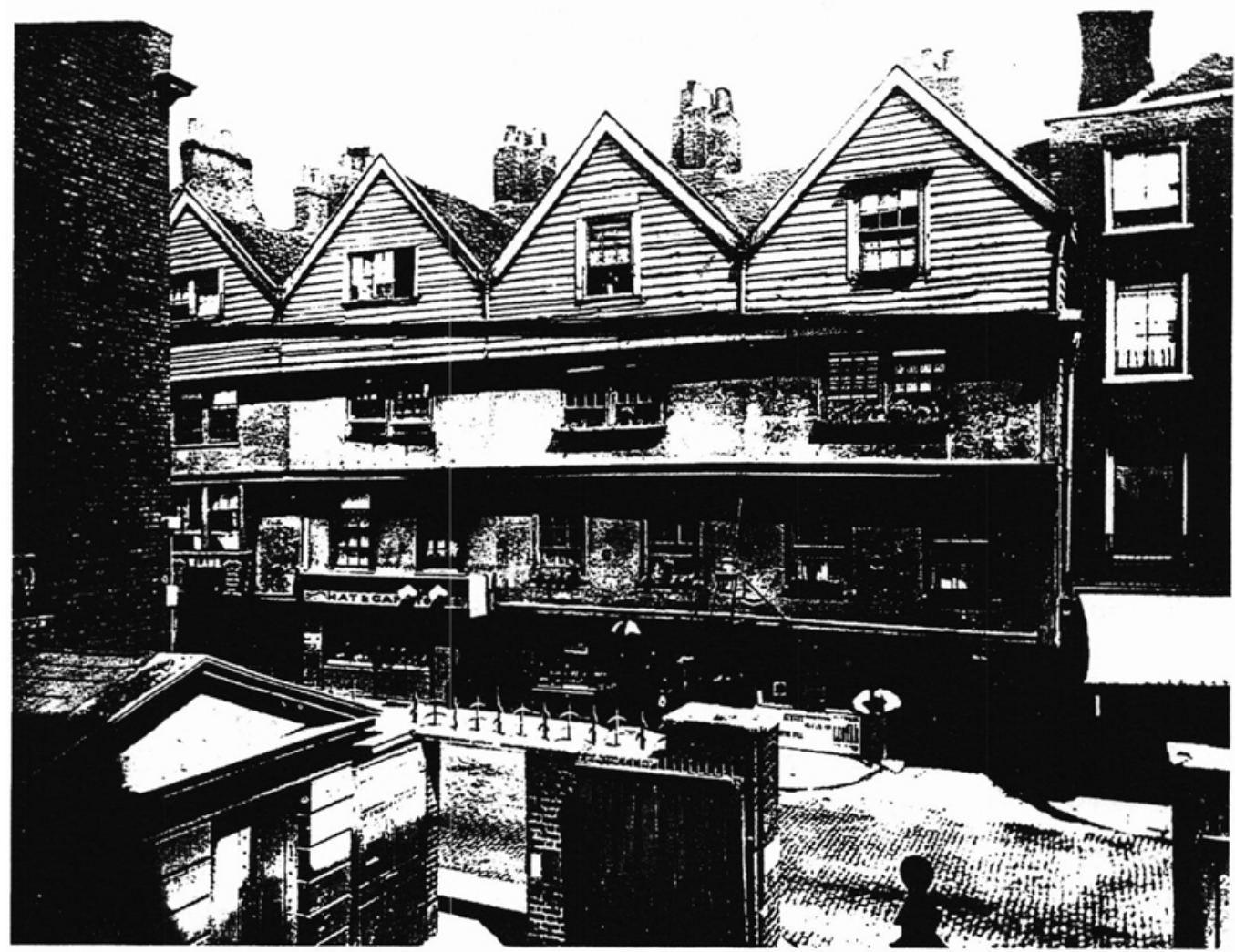




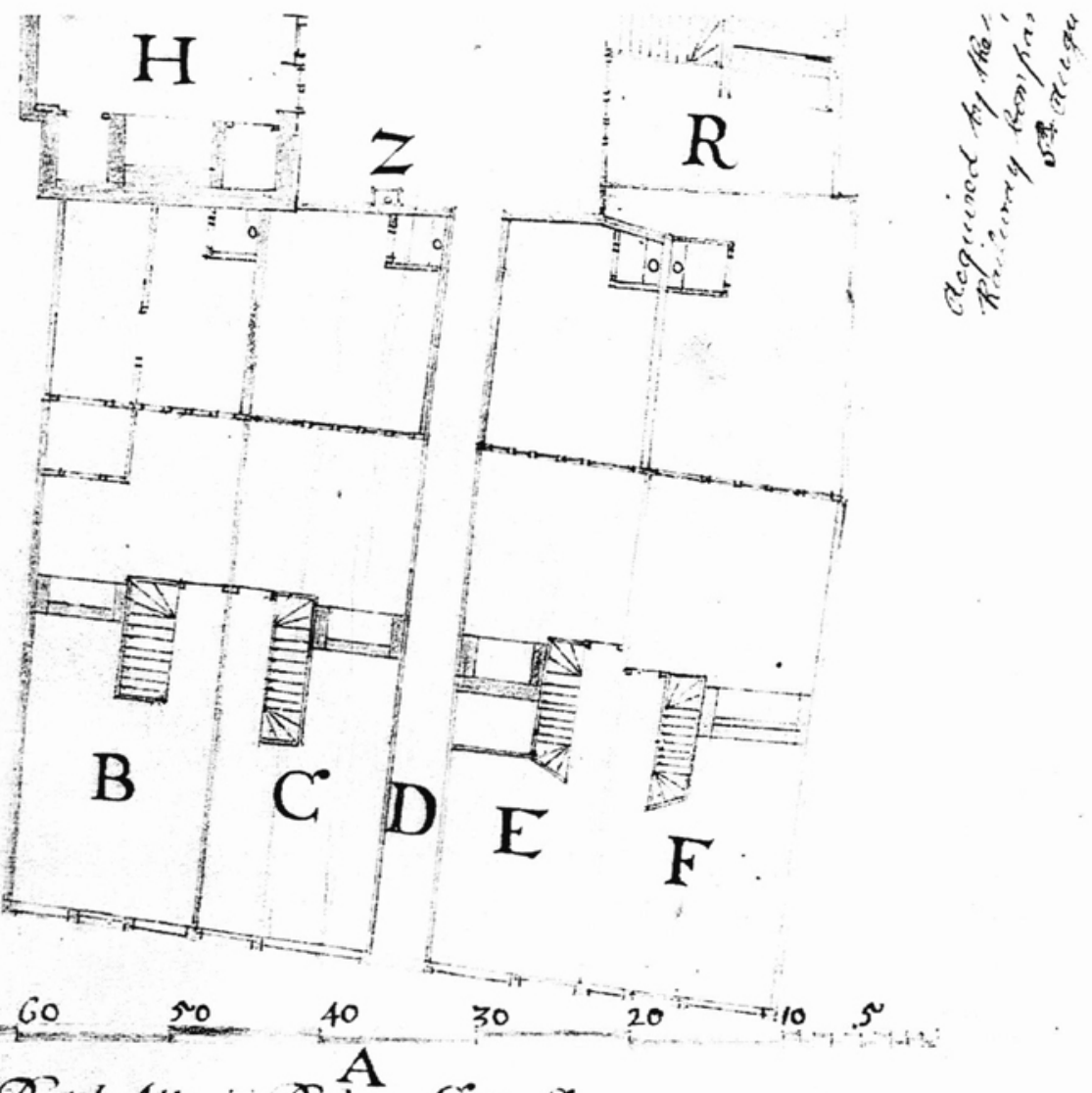

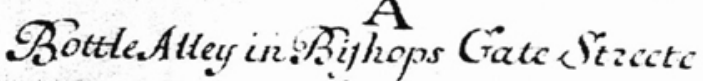

Illus. I 3. Nos. I $81-84$ Bishopsgate, plan of 1679 , copyright Guildhall Library and Company of Armourers and Brasiers

arrangement, preserving its winder stair entirely. Each house was of three storeys with attics and cellars, jettied at the first, second, and attic floors.

Nos. I 8 I -84 Bishopsgate were of similar plan and construction, built between I 58 I and 1627. The arrangements are given on a plan and accompanying description of I679 (Guildhall Library MSS I 2 104, I 2 I 30). Each house was of three storeys with cellars and attics, jettied $\mathrm{I}$ foot $(0.30 \mathrm{~m})$ at the first floor, and $\mathrm{I} 8$ inches $(0.46 \mathrm{~m})$ on the two floors above, with jettied windows on the first and second floors (Illus. 1 3). Each was of identical depth and plan, of two rooms on each floor with the stairs placed centrally to one side of the chimney stack. The ground-floor front room was an unheated shop; the rear room was the kitchen, paved with Purbeck stone. On the first and second floors there were two rooms, each heated; in the garret only the room at the front was heated. For each house there was to the rear a yard paved in Purbeck stone, containing both a buttery with two small rooms over it, and a house of easement. 


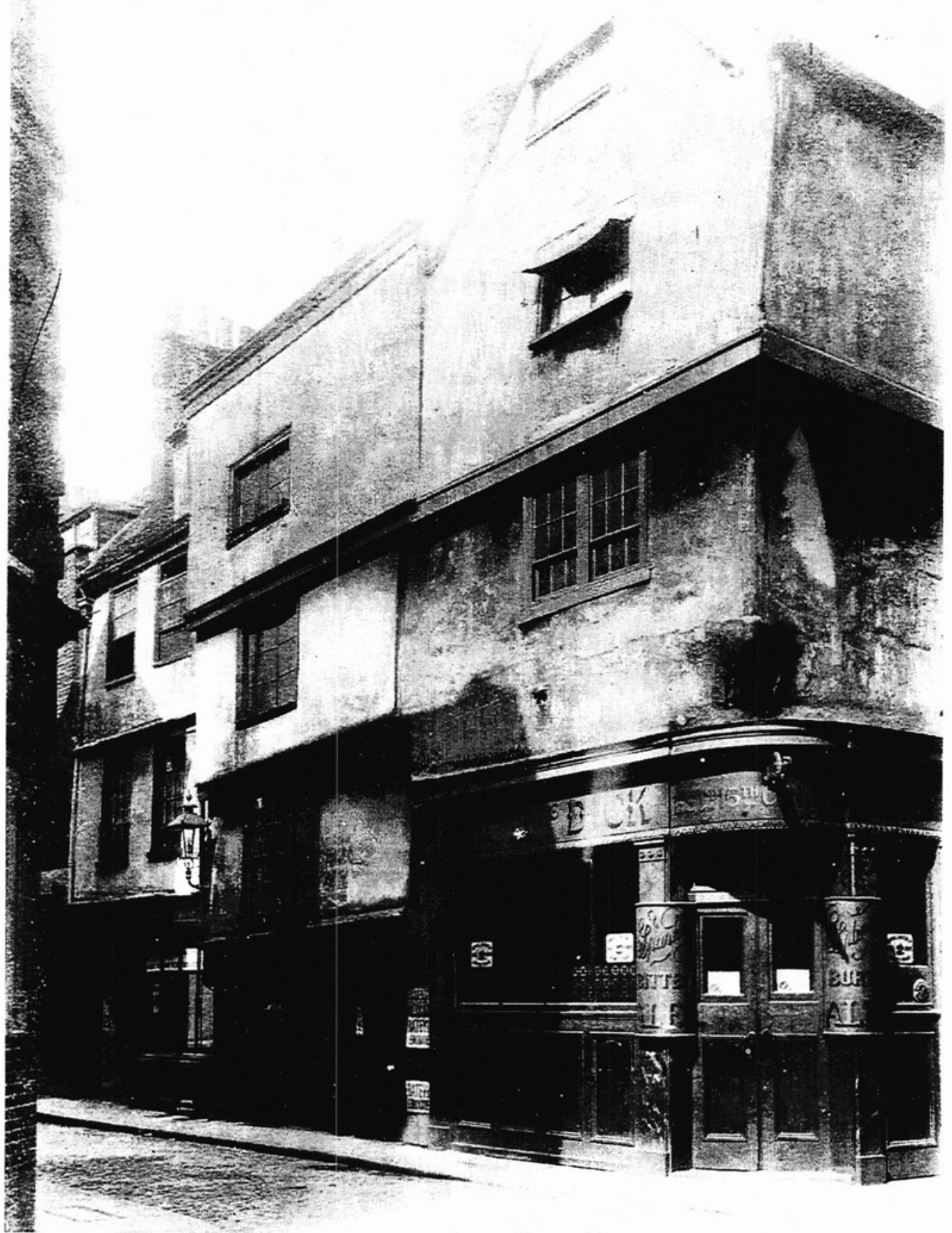

Illus. 14. No. 24 (the 'Dick Whittington') and no. 25 (see Illus. 3) built c. I 598 . The ground- and first-floor levels of no. 24 had possibly been altered to compensate for the rising street level, copyright Guildhall Library 


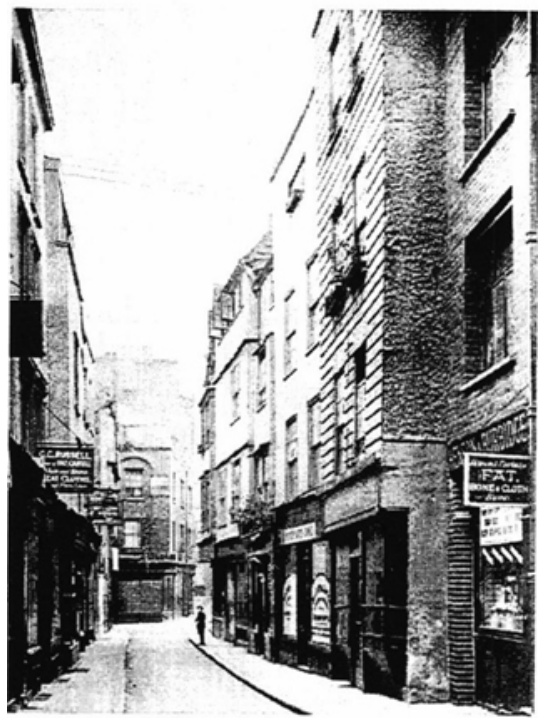

Illus. I 5. Nos. I 8-2 I Cloth Fair, houses jettied only at the first floor, copyright RCHME
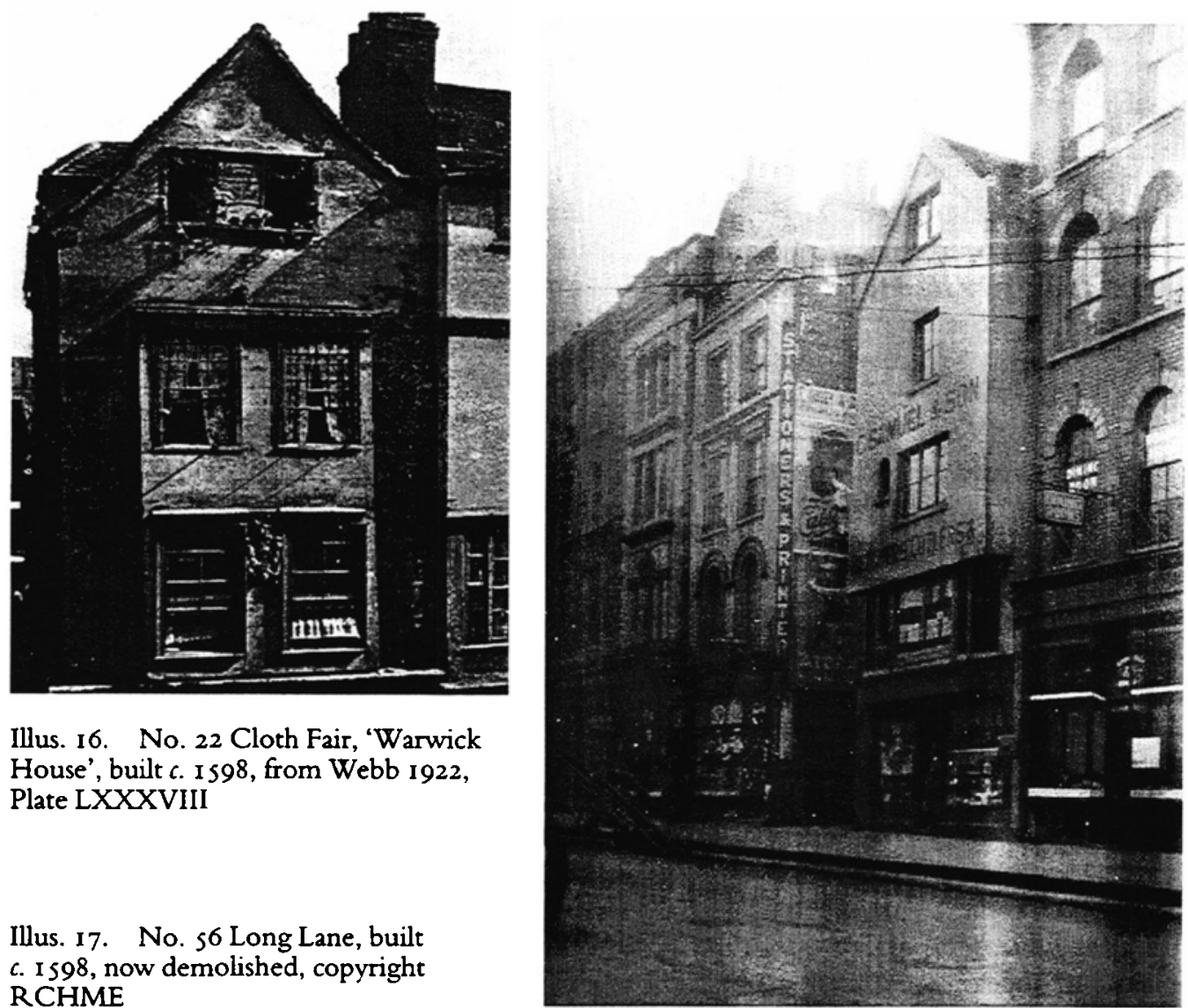

Illus. 17. No. 56 Long Lane, built c. I 598, now demolished, copyright RCHME 
The evidence from Southwark, Gray's Inn Lane and Bishopsgate shows therefore that houses of two rooms in depth, with the stairs positioned against a centrally placed stack, were being built in the suburbs of London from the 1580 and 905 . The correlation of estate records with early photographs and illustrations would probably reveal more examples, such perhaps as the three timber-framed houses of this plan recorded in Poplar High Street, no. 108 and at nos. 207-09, none closely dated (Survey of London I994, pls. I 2 and 73).

Research in progress has shown that this plan was being adopted in the seventeenth century in both south-east England, again in suburban contexts, and in Jamestown, the capital of Virginia until 1699 . In none of the examples so far traced has it been possible to assign an exact building date. The row of three houses (Structure 17) recorded by excavation in Jamestown (Cotter $1958,45-51$ ) is of particular interest in being of identical plan and near identical dimensions to the Gray's Inn Lane houses. Excavation and documentary research (by the Colonial Williamsburg Foundation as a reassessment of the archaeology of Jamestown, by Carl Lounsbury, the author and others) has indicated that these houses date from the I660s; the appearance in Moxon's Mechanick Exercises (I684) of a similar plan was thought to lend support to this view (Horning 1994). The evidence from Southwark, nos. 6I-65 Gray's Inn Lane and nos. I 8I-84 Bishopsgate, and the absence of this plan type from the later seventeenth-century examples cited by Kelsall (op. cit.) would equally well allow for a date in the first half of the seventeenth century.

\section{THE TIMBER-FRAMED HOUSES}

From the corpus of more closely dated houses of the late sixteenth and early seventeenth centuries now available, and from the evidence that this provides for the construction of jetties to street frontages, it is clear that a change in building practice and architectural design was in progress in this period. Some of the houses built in the I 590 s and I60os were jettied at each floor, very much in the medieval tradition. Examples are the houses in Gray's Inn Lane of 1595 and nos. 24-25 Cloth Fair built c. I 598 (Illus. 12 and I4; see also Illus. 2). Other houses, a far greater number, were built in this same period as jettied at the first floor only. Examples include nos. 6-9 Cloth Fair (Illus. 7), nos. I 5-22 Cloth Fair (Illus. I 5; Schofield 1995, I76; Illus. I6; see also Illus. 4), and nos. 56 and 74 Long Lane (Illus. 17 and $5-6$ ).

It is also evident from the redevelopment of St Bartholomew's Fair that in the late I 590 building in timber-framed construction was still the norm. Equally, such houses continued to be built into the seventeenth century, for instance the greater number of the houses in Kentish Row, built from I6I 3 onwards.

Dated examples in the decades preceding the Great Fire are more difficult to identify. One is certainly the two rows built on either side of Winchester Street c. 1656. This street was situated within the former precinct of the Austin Friars, extending south from London Wall. On the west side was a row of eight houses, gabled end on to the street, jettied only at the first floor, each of three storeys and an attic, and overall of a uniform design. As shown on Ogilby's map of 1677 they would appear to have been of one room in depth. On the east side was a row of nine houses, of similar appearance, but possibly of two rooms in depth (Illus. I8; Smith I8I5, 


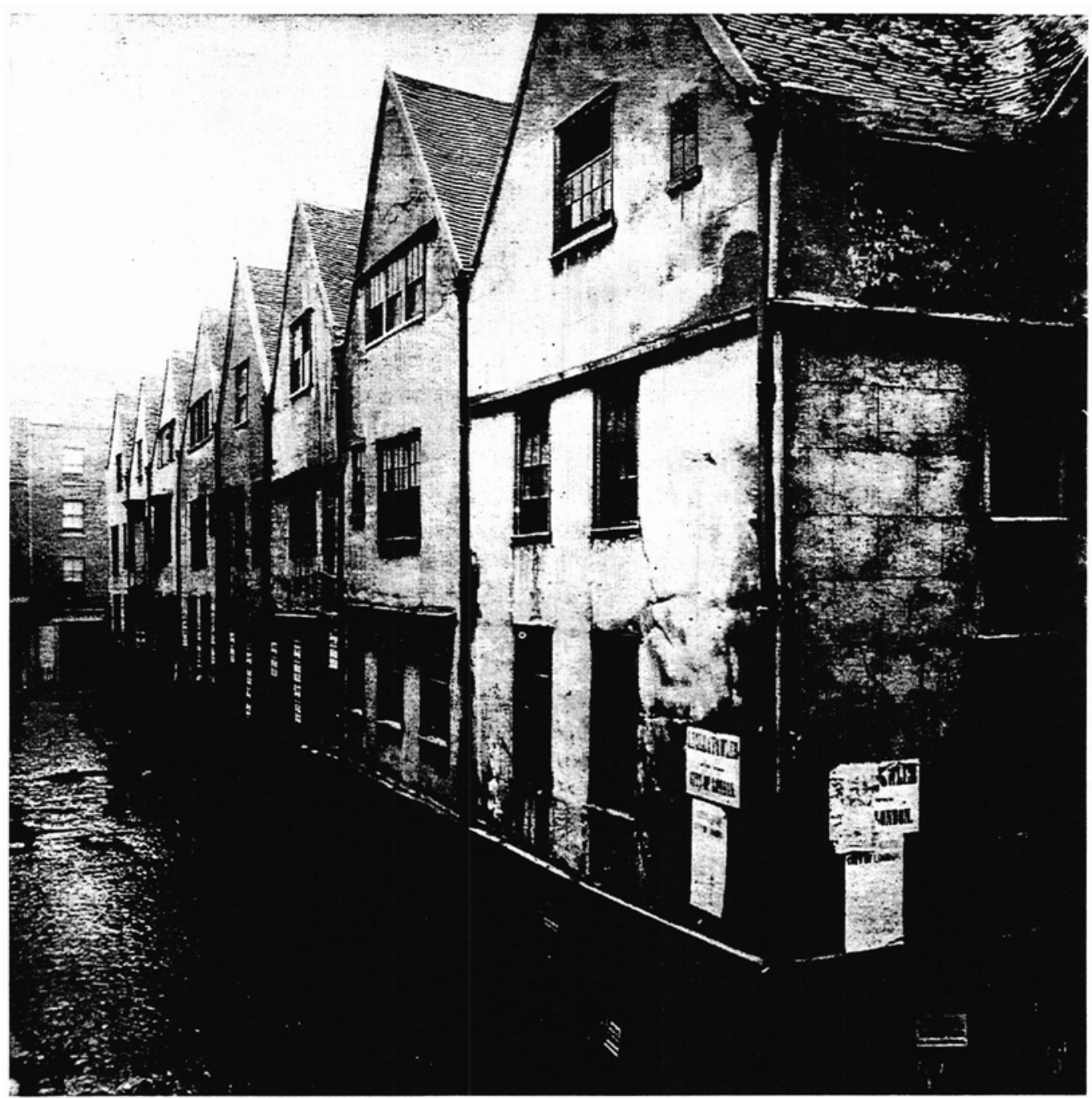

Illus. 1 8. Winchester Street, looking south, Gerald Cobb album, Mansions in or near the City, III, copyright RCHME

68-70). The date for the construction of the two rows comes from a late nineteenthcentury observation: 'from a date carved on a grotesque bracket formerly to be seen at the north-east corner, it appears that the street was constructed, partly at least, in the year I656' (NMR Gerald Cobb Album vol. IIIB).

\section{THE USE OF BRICK}

Study of the Treswell surveys indicates that buildings of brick, though scattered through the City, were still comparatively rare in early seventeenth-century London 
(Schofield 1987, 28). The houses of the St Bartholomew's Fairground development provide the first evidence for large scale building development in brick in London.

The 1616 survey of the St Bartholomew's estate was concerned with the present and potential value of the individual tenancies. Brick construction was seen as superior, adding to the value of a house or row, and was therefore duly noted in the survey. The Is houses in Rugman's Row, later Newbury Street, were 'uniformally built with bricke'; in Kentish Row one group of four tenements were noted as being of brick, as were William Cossen's six tenements in Courthouse Row. In the same row 'one faire brick house' in Henry Haward's six tenements was singled out; the remaining houses were presumably of timber-framed construction. In Thomas Roger's buildings in Launders Green on the north side of Cloth Fair, two houses were newly built in brick, while a third was of brick to the first floor, timber-framed above. In Kelshawe's Row, in contrast, the architectural evidence indicates that some houses were constructed in brick, but this is not highlighted in the 1616 survey.

The design and construction of some of these brick houses can examined through several recorded and surviving examples. In Kelshawe's Row, the two back-to-back houses at nos. 20 Middle Street and 5 East Passage (both since demolished) were built in brick. Clapham recorded in I9I I that the elevation to Middle Street was in dark brick with red brick dressings and bands between the storeys (Illus. 7). The original attic (deleted and fourth substituted, but third must have been intended) windows were partly blocked up with weather boarding and modern brickwork was carried up at the sides. The first and second storeys each had three windows, two with modern frames and a small more ancient window on the east side to light the staircase. The elevation to East Passage was similar but here the frames to the ground-floor entrance and the second-floor windows were original (Illus. 8). Again there were two small original windows to light the staircase. No. 6 East Passage appeared to be of the same construction with plat bands at the same level between the storeys. The elevation was plastered. Phillips' photograph of the elevation of no. 2I Middle Street indicates that while the front was clearly reconstructed, the floor levels remained the same as the adjacent no. 20.

A number of examples of larger town houses built in brick from the later seventeenth century onwards and later refaced or rebuilt could be cited, including nos. 14-15 Newbury Street (see Appendix 3). It could therefore be argued that Clapham was looking here at houses rebuilt in the later seventeenth or early eighteenth centuries. In this context the Royal Commission's photographs of nos. 20 Middle Street and 5 East Passage provide vital evidence for the probable construction date of these houses. The arrangement of the façade, with two principal windows and a smaller one to one side, occurring in each at both the first and second floors, is totally uncharacteristic of post-Fire houses. The placement of the small windows, narrower and of lesser height than the principal openings, can be paralleled most closely in the early seventeenth century rows of Great Yarmouth (O'Neill I953, I45 etc.).

Two of the brick houses built $c$. I614 still survive, though much altered (Illus. I9). The six leases listed for 'the I I houses upon the square in Launders Greene' were granted in 1614 , all but one on the feast of St Bartholomew. These can be identified as the block of houses on the north side of the Cloth Fair, bounded on the east and west 


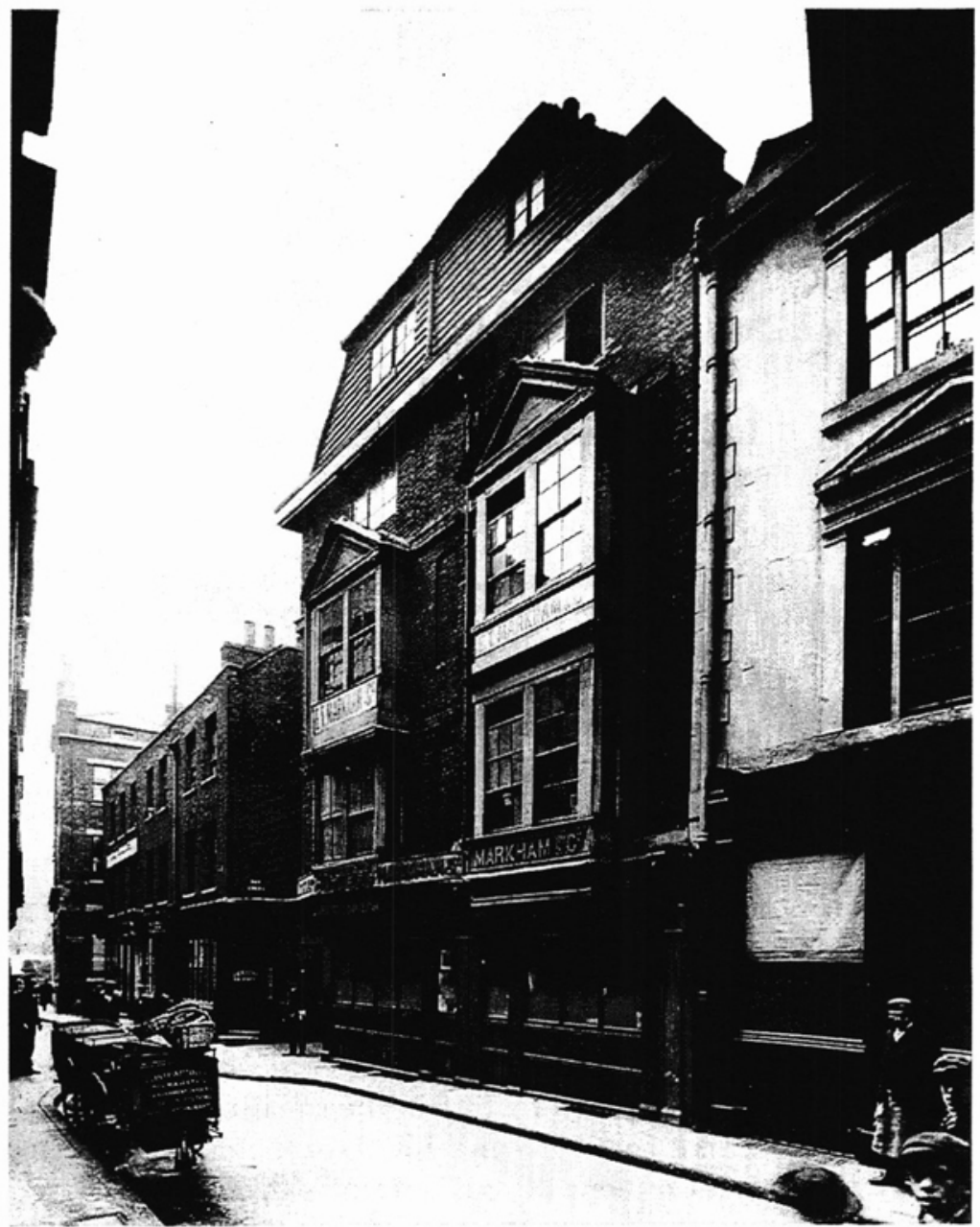

Illus. 19. Nos. 4I-42 Cloth Fair, part of the Launders Green development, built in brick c. 16 14 , before restoration by Seely and Paget of 1930, copyright RCHME

by New Court and Sun Court respectively, on the north by the lane running between the two. The leases granted in 1614 give the measurements of most of the plots and enable the individual tenancies to be identified. One house was larger than the rest, being in 1616 'two tenements arranged as one new built of brick', held by William Chapman and containing two cellars, two shops, four chambers and two garrets. Opening 'both south and west' it can be accurately identified as being no. 42 Cloth Fair, excluding the northmost of the two bays fronting on to New Court. Adjacent to this was a house of one room in depth, explicitly identified in the following entry as 'one other of the same tenements'. This is now no. 4I Cloth Fair.

Nos. 4I-42 were recorded for the Royal Commission inventory, though the investigator (from the handwriting neither Clapham nor Phillips) is not recorded. In 

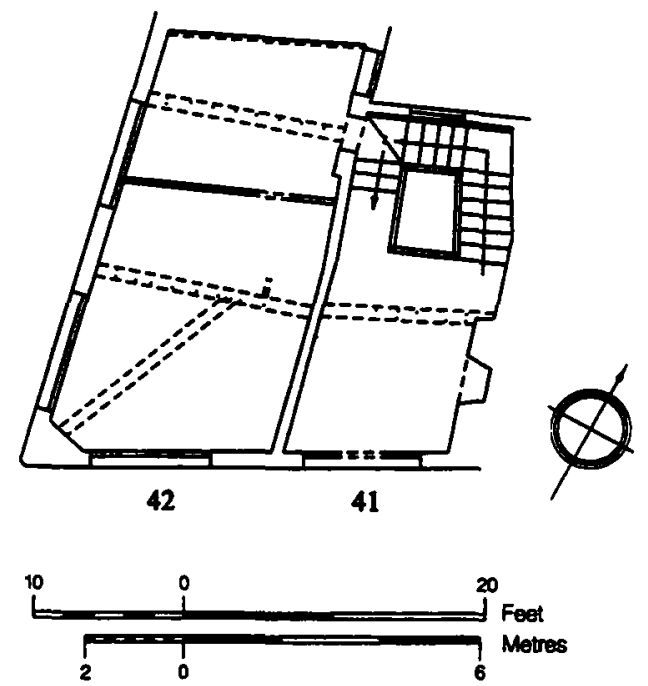

Illus. 20. Nos. $4 \mathrm{I}-42$ Cloth Fair; internally the basic outline of the three original houses is preserved. Based on field survey and plans by Seely and Paget of 1930

the published inventory the building was assigned to the 'second half of the seventeenth century' (RCHME 1929, I65 and pl. 203). In 1930 the three houses were extensively restored by the architects Seely and Paget, responsible for much work on London churches between the wars and whose intent was to preserve as much of the original structure of nos. $4 \mathrm{I}-42$ as possible; they were also clearly aware that the houses were built in 1614 (City Press 7 February 1930). Use of their plans has been combined with field observation to provide the following analysis of the original form of nos. 4I-42.

The south and west elevations were built in a near English bond, of two inch brick, with plain plat bands at the first and second floors, and a moulded band to the one above. The window frames of the bay windows, before $c$. 1930 concealed by inserted sashes (ibid.), are certainly late seventeenth century, but the flattish pediments over them are redolent of the moulded brick pediments on no. 5, Row 99 and no. 25 South Quay, Great Yarmouth, the latter of I644 (O'Neil 1953, I49 ff.). Immediately to the east of the bay windows to no. 42 are two narrower window openings. These were evidently unblocked in 1930 . The two hipped roofs with a modillion cornice together with the moulded plat band are of the late seventeenth century and belong to a raising of nos. $4 \mathrm{I}-42$, possibly by then one house, to a full four storeys.

Internally the basic outline of the three original houses is preserved (Illus. 20). In no. 4I the original stack position was possibly between nos. 4I and 42 , as indicated on the plan of 1930. An early addition to no. 4I was the small crosswing containing the framed staircase extant in 1930; the exposed collar-beam truss to the slightly lower roof forming its exterior gable remains in situ. The original stack and stairs positions are problematic. The stack between nos. 4I-42 was removed in 1930 and the stairs 

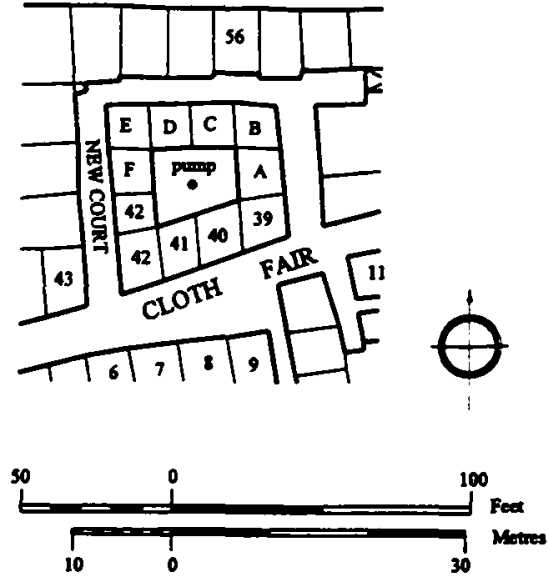

Illus. 21. Launders Green, suggested layout as planned and built c. 1614, based on analysis of the Ogilby plan of 1677 and of the OS plan of 1873 , utilizing data from field survey

between nos. 42 and $42 \mathrm{~A}$ is of two builds, the earlier part being the balustrade to the third floor, the later the balustrade of the stairs from the second to third floors. If in situ it is uncertain whether the stairs were intended to serve either no. 42 or $42 \mathrm{~A}$, or indeed both. Nevertheless, nos. 4I-42 can confidently be identified as two surviving houses of those built in Launders Green 1614-16. It is improbable that these two houses would have been rebuilt in brick in the second half of the seventeenth century to the same small floor area and the same number of storeys as when first constructed less than seventy years earlier, and to a complex plan which is best explained as an adaptation of the original layout. They can therefore be considered alongside the houses in Middle Street and East Passage.

From the surviving three brick houses at $4 \mathrm{I}-42$ Cloth Fair, and from photographs of those in East Passage and Middle Street, we can draw some general albeit tentative conclusions about the appearance and construction of the first streets in London built wholly or partly in brick. The brickwork was in English bond. Plat bands between the storeys provided internal ledges for floor joists. Alongside the main fenestration were smaller windows to light the stairs. The absence of these from the façade of no. 4I Cloth Fair may have its origin in the circumstances of Bartholomew Fair. The evidence from the 1616 survey indicates that these houses had a rear access for use of the occupants at the time of the fair. These entrances from the inner courtyard of the square would not have served any useful purpose if access from the rear was through the ground-floor shop to then ascend a stairs at the front of the house. The one room houses in the corners to the square would not have been able to enjoy such access, hence the provision of a stairs window opening to no. 42 , which had possibly reached this stage of building before it was decided to make it and no. 4I one house. This in 
turn would have led to the early indeed near contemporary blocking of the same window openings, unnecessary with a more central stairs being provided elsewhere.

In the redevelopment of St Bartholomew's Fair, the rows redeveloped from I 597 onwards were of timber framed construction. The use of brick for exterior walling seems to have been adopted in the second decade of the seventeenth century. While superior developments of the 1630 s onwards were clearly being built in brick, more research would be necessary to determine the extent to which by the r66os brick had replaced timber-framing as a preferred walling material for lower status housing. The evidence from Winchester Street shows clearly that timber-framed houses were continuing to be built into the I65os.

The building of streets of brick houses nearly two decades before the construction of the piazzas of Covent Garden will come as a surprise to some readers, particularly those immured in the comfortable belief that innovation must be the role of the Court or urban élite. In this writer's view the evidence contained within the 1616 survey and in the Royal Commission's records and photographs is unequivocal.

\section{AMENITY AND THE PROSPECT OF IMPROVEMENT}

The I6I6 survey of St Bartholomew's Fair held out not only the prospect of increased rental, but that of amenity and improvement. This was most evident in the last phase of redevelopment from I6I3 onwards. The rows built from 1597 onwards occupied the same positions as the rows of booths in the fair. From I613, a more imaginative approach was taken. The arrangement of the new houses broke through the constraints of the medieval rows of booths, the provision of fresh water supply was brought into the building scheme, and the design, setting and aesthetic appeal of the row as a whole assumed greater importance.

The building of Courthouse Row was a halfway stage in this process. The leases of new plots for building did not envisage its extension beyond the spaces occupied by the earlier booths. The dimensions of the plot leased to Henry Haward in I6I 2 show that at that stage his new property was to be occupied entirely by a row of new tenements 20 feet $(6.10 \mathrm{~m})$ in depth, slightly narrower than the plot to the west leased to William Cossen in 1608 . The decision to provide the later rows with rear yards was probably not taken until I6 13, when new leases for most of the houses in Kentish Row were granted. Prior to this the booths in Kentish Row were accessible from north and south. With the redevelopment of Kentish Row, it was possible to add small yards to the houses in Courthouse Row to the north, as well as provide the new houses in Kentish Row with slightly larger yards. This process was continued in the next year with the development of Rugmans's Row, where each house was given a yard of similar size to those in the Courthouse Row.

The development of the I I houses around Launders Green, started in I6I4 and complete by 1616 , was also a departure from earlier arrangements. The precise layout is described in the six leases granted in November and December 1614, and delineated on Ogilby's plan of 1677 and on later maps. Allowing for one house (later no. 42 Cloth Fair) having been two plots joined together in the initial granting of leases, the intention was to provide plots for I I houses, ranged around a central courtyard, each 
house of more or less equal size (Illus. 2I). There is no mention of earlier booths in the leases, and it is clear from these that the new 'court comon to all those tennants' was formerly waste ground. It is also evident that Gilbert Thacker in 1616 certainly saw the development as that of a square, entitling this section of his survey 'the I I houses upon the square in Launders Greene' and concluding with comments on the attractions to be found 'in the middest of this square'. It would be of great interest to know if the II new houses were also intended to be of uniform design. Only the three intended tenements contained within nos. 41-42 Cloth Fair were certainly of brick and uniform design; for the remainder no comments are made in the 1616 survey.

These same developments were the first to be given their own water supply. This is highlighted in the 1616 survey and was clearly seen to give added value to the tenements in these rows. The pump sited in the centre of Courthouse Row would have served the houses in this row and Kelshawe's Row. The tenements in Rugman's Row were similarly provided having 'amongest them the benefitt of a pump standing in the streete about the middle of the rowe'; this would also have served the houses in Kentish Row on the other side of the street. In the court within the square formed by the II houses in Launders Green was 'a pumpe of very pure water in the middle thereof'.

It is very evident from the 1616 survey that the situation of a house could contribute to its rental value. In noting these possibilities, Gilbert Thacker revealed his own aesthetic views. These were not confined solely to the later developments within the fair. Some of the earliest houses were well sited. In describing nos. 3-9 Cloth Fair, built $c$. I 597 onwards, the survey noted that 'thus farr all these tenements have prospect backward into the churchyard'. On the opposite side of Cloth Fair, Thomas Rogers had leased what was probably an older property, within which the survey notes was a 'pretty court or yard'. Particularly attractive was probably the view southwards from Rugman's Row. All the tenements had 'prospect backwardes into the gardens of Sir Henry North and Mr Doctor Martin'. Clearly Thacker's perception of the fair was very different from that of Ben Johnson.

In these matters of improvement, aesthetics, and their links to rental values the redevelopment of St Bartholomew's Fairground can be seen as a milestone in London's building history. Here were built the first rows of brick tenements; here was evident the emphasis on improvement and amenity so characteristic of the post-medieval building promoter. This was neatly encapsulated in the prospect from the uniformly built brick houses of Rugman's Row, perhaps the best location in London's first post-medieval speculative development, southwards over the gardens of superior residences to the still standing walls of the crowded city beyond.

\section{ROWS AND TERRACES}

Nevertheless, the new rows of the St Bartholomew's Fairground redevelopment were emphatically part of a continuum. Medieval rows were characterized by a shared identity. Individually, the rows of St Bartholomew's Fair each had their own identity as a row through being built at a particular point in time. There were also elements of a common economic and tenurial identity. Each row embodied a reuse of existing booth sites and leases. All were part of an estate managed for profit. They were known 
to contemporaries as rows, and take the history of the medieval row forward into the late sixteenth and early seventeenth centuries.

Within these rows, blocks of new houses were characterized by a common structural identity. On the south side of Cloth Fair, no. 22 and the houses behind, formerly Harthorne Row, and nos. II-I2 and $\mathrm{I}_{3}-\mathrm{I} 7$ Cloth Fair certainly appear from early illustrations to have been built as one (Illus. 4; Schofield 1995, 176). Elsewhere in London we can point to speculative developments resulting in the construction of groups of houses built to a common plan. The seven houses of similar but not identical two room plan at nos. 29 I-99 Borough High Street, Southwark recorded in 16 I I (see above), were all probably part of the estate formerly of St Mary Overey's priory (Schofield 1987, I 38-39). In Bermondsey Street, Southwark, the estate of Queen's College, Cambridge, was being developed in the I 550 . Five plots on the west side of the street were let for building between $1558-60$, eight houses being built altogether (Queen's College archives box 25). The four houses built in I 595 in Gray's Inn Lane were of identical plan and were clearly built as a single row. The four houses built at nos. I 8I-84 Bishopsgate between I 58I and I 627 constituted a similar row, this time of slightly different plan, the ground-floor front rooms being unheated and intended to be shops. The two rows on each side of Winchester Street, built c. I656, were part of the same building tradition (above).

Looking at later seventeenth-century developments it is evident that rows of houses, built to rent, continued to be called 'rows' when built and when in use. This is most obviously so in the rows of Great Yarmouth, the initial construction of many of these still yet to be closely dated, but largely rebuilt in the seventeenth century (O'Neil 1953). It is equally apparent in the evidence from London, and not only in the redevelopment of St Bartholomew's Fair. The three sides of Lincoln's Inn Fields, developed by 1659 , were known to contemporaries as 'Newman's (later Turnstile) Row', 'Arch (later West) Row' and 'Portugal Row' (Survey of London 1912, 12).

Outside London ranks of houses built together continued to be called 'rows' into the eighteenth century. In Bristol the four sides of Queen Square built c. I 700-ro were the 'East, North, South and West Rows'; 'Chapel Row' was laid out for building c. I720 (Ison I978, I40 ff., I 58). In Portsmouth a conveyance of I 849 refers to 'a newly formed Row or Terrace called Lion Esplanade' (Portsmouth RO D I / 468 ).

The large numbers of rows of smaller houses built after the Fire have generally been referred to by architectural historians as 'terraces'. Summerson wrote of Barbon and his 'particular brand of terrace house' (ibid., 49). Cruickshank and Burton (I990) in enlarging upon the study of the Georgian town house, of London in particular, have continued to describe rows of such houses as 'terraces' (ibid., I00-03). Juxtaposed against the medieval 'row' this has served to enhance the impression of a complete break between the medieval and post-Fire building traditions. This has left North American colleagues, familiar with row houses in a post-medieval context, sufficiently puzzled to wonder if there was in fact a break between the building of 'rows' in medieval times and the building of 'terraces' in post-Fire London and other towns, to the extent that structure 17 at Jamestown has now been named variously a 'terrace' and a 'terrace row' (Horning I994, I7). The attribution of the term 'terrace' to medieval rows, 'a Terrace of Crucks at Much Wenlock' (Moran 1994, 34) et al., will 
presumably have caused even greater bewilderment (see also Charles 1979, 93; Quiney 1995; Williams 1979, 145). Preferable would be the use of the term 'row' or 'range', both used in a medieval context though not without their own ambiguities.

The use of the term 'terrace' even for early eighteenth-century developments is undoubtedly an anachronism, although now very well embedded in architectural history; it was possibly first used to describe the Adelphi, a row raised up as though on a terrace, in I 769. Its application has been most misleading in a seventeenth-century context, for there its use has served to conceal the continuity in perceptions of house building practice from the medieval period to London after the Fire. Great Queen Street was reputed in the eighteenth century to constitute 'the first regular street in London' (Summerson I969, 34), and certainly owed something to Italian taste. Two decades earlier Rugman's Row was the first street built uniformly in brick, and Launders Green might be considered as London's first seventeenth-century square. The houses built in St Bartholomew's Fair, Gray's Inn Lane, Winchester Street and elsewhere provide an important link between the row houses of medieval English towns and the rows of later seventeenth-century London. For the greater part of the eighteenth century and for the preceding centuries we would do well to abandon the term 'terrace' in favour of 'row' or 'range'.

\section{THE HUMBLE REALITIES OF MATERIAL LIFE}

The foundations of later seventeenth-century and Georgian house building in London can be seen to lie not only with the dramatic events of the seventeenth century, first the introduction of Palladianism to England and then the speculative building of the I660s onwards. To Summerson's foundation stones of taste and wealth we can now add that of the long established urban building tradition, as evident in the late sixteenth and early seventeenth centuries. If we look at the longer term development of urban housing in sixteenth- and seventeenth-century London, the broad spectrum from poor to rich, we see a slower rhythm.

'Taste in architecture' as defined by Summerson was 'a luxury import', 'the exclusive, snobbish sense of the recognition of certain fixed values by certain people' (ibid., 27). A more widely based taste was probably long lived but rarely revealed. The aesthetics and taste of Gilbert Thacker, articulated in the survey of 1616 , were both a reflection of and a rare insight into the tastes of those who might lease houses such as those in Launders Green and Rugman's Row.

The practices employed in speculative building were certainly altered by the postFire legislation, but had been similarly modified by medieval ordinances. The innovations seen in the planning and construction of the smaller houses of late sixteenth- and early seventeenth-century London, notably the building of London's first brick rows, executed by building craftsmen for tradesmen, artisans and their other humble contemporaries, were part of a long process of change, to which the architectural innovations of Covent Garden and the like also made their own significant contribution. Further research might well show a continuum between the building craftsmen working in St Bartholomew's Fair and those later employed in Covent Garden and in succeeding schemes. Summerson (ibid., 29) pointed to the Earl 
of Bedford's developments along Drury Lane and in Long Acre as predating his project for Covent Garden; these must have been amongst the larger building schemes of the early seventeenth century, in scale matching that of St Bartholomew's Fair and certainly part of that continuum.

There was little difference in plan form between the brick one-room deep houses of Launders Green and Rugman's Row of the I6ros and those being built in Elder Street, Spitalfields, in the I720s (Cruickshank and Burton 1990, 209-20). Kelsall's work (op. cit.) had already indicated the probability that the larger post-Fire house owed more to what had gone before than had generally been realized. The precedents are now much clearer. The timber-framed houses of two room plan identified in Bishopsgate, Gray's Inn Lane and Southwark can now be seen as the precursors of the post-Fire two room houses. Kelsall's study remains our best available perspective on practice in the last three decades of the seventeenth century, within the areas of higher class housing and mainly to the west of the City devastated in 1666.

Of the greater part of the City itself we are less well informed. The Monument designed by Wren to commemorate the Great Fire records that I 3,200 dwelling houses were consumed. It has not been generally appreciated that of the ro,000 or more new houses built to replace these, and of the subsequent late seventeenth-century developments of smaller houses beyond, we still know almost nothing. From what followed, and from went before, it is likely that the humble realities of material life will have been such that innovation and change were part of history in the long term.

\section{ACKNOWLEDGEMENTS}

The final form of this paper owes much to the generous help given by friends and colleagues. I am especially grateful to Edward Chappell, Peter Guillery, Bernard Herman, Derek Keene, Carl Lounsbury, and John Schofield for offering suggestions and sharing ideas. Responsibility for what is written rests entirely with the author. Susanne Ferguson, Brian Hopper, Veronica Smith, and other colleagues in RCHME all provided much help in the identification of maps, photographs, and other sources; I am equally grateful to the archivists in the City of London and Bristol Record Offices, the Cambridge University Library and the Guildhall Library for their assistance. A special debt is owed to the early Royal Commission investigators, particularly A. W. Clapham and A. T. Phillips, without whose notes and photographs this paper could not have been written, and also to Tom WinrowJones for his kindness in providing access to earlier records and making possible the survey of nos. 41-42 Cloth Fair.

Finally and most importantly I must thank my family, both Pamela Leech who has endured the reading of this text on more than one occasion and my mother whose organization in the early 1950s of childhood visits to London in the company of my sister and I-Spy London provided a lasting interest in the Priory of St Bartholomew and its environs.

\section{BIBLIOGRAPHY}

Bentley, D. 1984. 26-36 Cloth Fair, 62-7 Long Lane, London Archaeologist, 4, 385

Bickley, F. B. (ed.) I900. The Little Red Book of Bristol, I and 2, Bristol and London: Hemmons and Sotheran \& Co.

Bowen, J. (and others) 1986. Interim report on work carried out by the Canterbury Archaeological Trust, Archaeologia Cantiana, 103, r91-234 
Braudel, F. I98I. Civilisation and capitalism: the structures of everyday life, London: Collins, translated from the French edition of 1979

Charles, F. W. B. 1979. Timber-framed houses in Spon Street, Coventry, Trans. Bimingham $\mathcal{E}$ Warks. Archaeol. Soc., 89, 91-I 22

Cotter, J. L. 1958. Archaeological Excavations at Jamestoun Colonial Histonical Park and Jamestown National Historic Site Virginia, Archaeological Series, 4, Washington D.C. : Department of the Interior

Cruickshank, D. and Burton, N. 1990. Life in the Georgian City, London: Viking

Downes, K. 1979. The Georgian Cities of Britain, Oxford: Phaidon

Harding, V. and Wright, L. (eds.) 1995. London Bridge: selected accounts and rentals, London Record Society, 3I, London: London Record Society

Harris, R. B. I994. The origins and development of English medieval townhouses operating commercially on two storeys, D.Phil thesis, University of Oxford

Hibbard, G. R. (ed.) 1977. Ben Jonson: Bartholomew Fair, London: A. \& C. Black

Horning, A. J. 1994. A Row of Fayre Houses: The Role of Town Planning and Real Estate Speculation in the Construction and Destruction of Jamestown's Terraced Houses, Jamestown Archaeological Assessment Newsletter, I, I6-18

Jones, S. R. and Smith, J. T. 196r. The Wealden houses of Warwickshire and their significance, Trans. Birmingham \& Warks. Archaeol. Soc., 79, 23-35

Jones, S. R. 1968. Gloucestershire: Tewkesbury, Medieval Archaeol., 12, 197

Kelsall, A. F. 1974. The London House Plan in the Later I7th Century, Post-Medieval Archaeol., 8, $80-9$ I

Keene, D. 1990. Shops and Shopping in Medieval London, in ed. L. Grant, Medieval art, architecture and archaeology in London, British Archaeological Association Conference Transactions for the year 1984, London: British Archaeological Association

Laithwaite, M., I995. Town houses up to I660, in (ed.) P. Beacham, Devon Building, an introduction to local traditions, Tiverton: Devon Books

Leech, R. 1981. Early Industrial Housing. The Trinity Area of Frome, Somerset. Royal Commission on Historical Monuments Supplementary Series, 3, London: Royal Commission on Historical Monuments (England)

Manchee, T. J. 1831. The Bristol Charities, Bristol: for T. J. Manchee

Moran, M. I994. Shropshire dendrochronological project-phase two, Vemacular Architecture, 25, $31-36$

Munby, J. et al. 1974. 126 High Street: the archaeology and history of an Oxford house, Oxoniensia, 39, 254-308

O'Neil, B. H. St J. 1953. Some seventeenth century houses in Great Yarmouth, Archaeologia, 95, I $4 \mathrm{I}-80$

Portman, D. 1966. Exeter Houses, 1400-1700, Exeter: University of Exeter

Quiney, A. 1995. John Schofield: Medieval London Houses, Soc. Archit. Hist. Newsletter, 56, 10-1 I

Royal Commission on Historical Monuments (England) 1929. An Inventory of the Historical Monuments in London. Vol. IV. The City, London: HMSO

-, I980. Ancient and Historical Monuments in the City of Salisbury, I, London: HMSO

- 1981. An Inventory of the Historical Monuments in the City of York, 5, The Central Area, London: HMSO

Salzman, L. F. 1967. Building in England down to 1540: a documentary survey, Oxford: Clarendon Press

Schofield, J. 1984. The Building of London from the Conquest to the Great Fire, London: British Museum Publications Ltd in association with the Museum of London

Schofield, J. (ed.) 1987. The London Surveys of Ralph Treswell, London Topographical Society Publication, 135

Schofield, J. A. I989. Secular Building in the City of London, c. I200-c. I600, D.Phil Thesis, University of London

Schofield, J. A. I995. Medieval London Houses, New Haven and London: Yale University Press

Short, P. 1980. The fourteenth-century rows of York, Archaeol. J., 137, 86-I 37

Smith, J. T. I 8 I 5 . Ancient Topography of London, London

Summerson, J. 1969. Georgian London, London: Pelican Books (1945 revised 1962) 
Survey of London, 1912. Survey of London, 3, The Parish of St. Giles-in-the-Fields, (Part I) Lincoln's Inn Fields, London: Greater London Council

Webb, E. A. (ed.) 1921. The records of St Bartholomew's Priory and of the church and parish of St Bartholomew the Great, West Smithfield, 2, Oxford: University Press for E. A. Webb

Williams, J. H. 1979. St Peter's Street, Nonhampton: Excavations 1973-1976, Northampton: Northampton Development Corporation

\section{APPENDIX I}

\section{NUMBERS OF BOOTHS IN ST BARTHOLOMEW'S FAIR}

Arranged in the sequence followed in the 1616 survey:

Rugman's Row

Kentish Row

Courthouse Row

Kelshaws Row

46

Longtyled Row

Close Gate Row

46 (some doubled up)

Hartehorn Row

Old Gallery 46

Newmans Row

Launders Green

Holmes's Buildings

36

Cloth Fair to Smithfield Gate

Long Lane

39

TOTAL 417

Source: Appendix 3

APPENDIX 2

SUMMARY OF PROBABLE NEW HOUSES IN ST BARTHOLOMEW'S FAIR, I 597-16I6

Rugman's Row

Kentish Row

Is

Kentish Row

IS

Courthouse Row I6

Kelshaws Row 17

Longtyled Row

Close Gate Row IO

Hartehom Row 2

Newmans Row

Launders Green 10

Holmes's Buildings 3

Cloth Fair to Smithfield Gate 7

Thomas Rogers Launders Green 3

Barleymow Passage 5 ?

Long Lane $\quad 46$

Total

175 of which 143 conformed to a standard plan

Note: the 12 tenements in the Old Gallery are omitted from this calculation; it is impossible to be certain as to the extent to which the new tenements were adaptations of the earlier booths.

Source: PRO SC $12 / 1$ I/39 and Appendix 3 


\section{APPENDIX 3 \\ THE REDEVELOPMENT OF ST BARTHOLOMEW'S FAIR-A SUMMARY LIST}

\section{Introduction}

This summary list is included to aid future research and to provide an economic means of referencing the preceding text. Streets are arranged in the sequence followed in the 1616 survey, as set out in Appendixes $\mathbf{r - 2}$. House numbers are taken largely from the Goad Insurance survey plans (in the Guildhall Library).

\section{Rugman's Row, now Newbury Street, $S$ side, nos. I-15, built 1614-I6}

Nos. I-2

Plot leased to Richard Thorne 18 June $161_{4}$ (PRO SC $12 / 1 / 22$ fol. 2), by I6I6 two tenements not of the standard plan (PRO SC I $2 / 1$ I $/ 39$ fol. 7).

Nos. 3-4 Plot leased to John Wister I 8 June I6I4 (PRO SCI $/ 1 / 22$ fol. I), by 1616 two tenements of standard plan, ground-floor rooms are halls not shops, with detached kitchens (PRO SCI2/I I/39 fol. 7).

Nos. $5-9$

No. 10 Plot leased to Christopher Jordain 18 June $\mathrm{I}_{6} \mathrm{I}_{4}$ (PRO SCI2/1/22 fol. I), by 1616 six tenements of standard plan (PRO SCI2/1 1/39 fol. 8).

No. 10

Nos. II-I 2

No. 13

Nos. I4-15 Plot leased to Peter Herdson 18 June 1614 (PRO SCI2/I/22 fol. I), by I616 one tenement of standard plan and one backwards of one and a half storeys (PRO SC12/I I/39 fol. 8). Plot leased to Thomas Waynwright 18 June 1614 (PRO SCI $1 / 1 / 22$ fol. 2), by I616 two tenements of standard plan (PRO SCI $2 / 1$ I $/ 39$ fol. 9).

Plot leased to Joseph Brett I 8 June $16 \mathrm{I}_{4}$ (PRO SC $12 / 1 / 22$ fol. 2), by 1616 one tenement of standard plan (PRO SC I $2 / 1$ I/39 fol. 9).

Plot leased to Thomas Swynhowe I8 June I614 (PRO SCi $2 / 1 / 22$ fol. I), by 1616 two tenements of standard plan (PRO SCi $2 / 1$ I $/ 39$ fol. 9); recorded in 1928 by Philips (NMR London, City of London inventory records). The early date and form of the rebuilding merit comment. Nos. 14 and 15 Newbury Street, formerty Rugman's Row, were recorded in 1928 by Philips who concluded that the two houses were built $c$. 1700. No. Is had been refronted and largely remodelled in modern times. No. I4 was of three storeys and an attic, gabled end on to the street, with plat bands to the first and second floors, and two principal windows on each of the upper floors; alongside these to the left were two very narrow blocked windows, that on the second floor not extending the full depth of the principal windows. The two houses are shown clearly on a photograph taken at the time of survey (RCHME London office, City of London inventory records). The documentary evidence for Rugman's Row enables exact identification of the widths of the plots initially leased for building. Nos. I4-15 occupied a plot c. 36 feet $(10.97 \mathrm{~m}$ ) wide (shown on plans for rebuilding in 1939, CLRO plan no. 0823), the combined width of two plots I 2 feet $(3.66 \mathrm{~m})$ and 24.25 feet $(7.39 \mathrm{~m})$, on which three houses had been built by 1616 . The two houses recorded by Philips must have replaced these three earlier ones. The gabled elevation and smaller windows to the side indicate that this rebuilding was of the seventeenth century. It should be noted that these smaller windows were taller than those of no. 20 Middle Street and no. S East Passage, and would not merit comparison with those of early seventeenth-century Great Yarmouth.

\section{Kentish Row, now Newbury or New Street, N side, nos. 16-30, built 1613-16}

Nos. I6-I 8

Plot leased to Thomas Swinho $c$. I613, by 1616 three tenements of standard plan (PRO SCi12/II/39 fol. I I).

Nos. 19-20 Plot leased to Peter Herdson c. 1613, by 1616 two tenements of standard plan (PRO SCr2/ i i/39 fol. I I). 
Nos. 2I-24 Plot leased to Richard Thorne $c$. I6I 3 , by 16 I 6 four tenements of standard plan (PRO SCI $2 /$ I I/39 fol. I I).

Nos. 25-26 Plot leased to Robert Penred I November 1614, by I6I6 two tenements of standard plan (PRO SCr2/11/39 fol. 12).

Nos. 27-30 Plot leased to William Dormer $c$. 1613 , by 1616 four tenements of standard plan (PRO SCr2/I 1/39 fol. I2).

Courthouse Row, later Middle Street, $\mathrm{S}$ side, built $c$. I 605 onwards

Nos. $1-2$

The Court House, later 'the Hand and Shears', lately built when leased to John Freeman 7 April I605, leased to Timothy Johnson 24 July I614, in 1616 let as four tenements, one including the great chamber where the court is held (PRO SCI2/1/22 fols. 7, 4 ; $\mathrm{SC}_{12 / 11 / 39}$ fol. $\mathrm{I}_{3}$; see engraving of 1828 in NMR London Red Boxes).

Nos. $3-8$

Booths, part of the row called the 'Bowleing Alley' leased to William Cossen 20 February 1608 (PRO SCI2/1/22 fol. 6), by 1616 six tenements of standard plan (PRO SCI2/I I/39 fol. I3).

Nos. 9-I4 Plot, dimensions given, the greater part 'builded with boothes', leased to Henry Haward I July I6I 2 (PRO SCI $12 / 1 / 22$ fol. 6), by I616 six tenements of standard plan (PRO SCI $12 / 1$ I $/ 39$ fol. 14).

\section{Kelshawe's Row, Micidle Street, $N$ side, built 1598-1612}

Nos. 27-28

Eight booths leased to John Kilsick 26 March 1598 (PRO SCI $2 / 1 / 22$

No. 26 fol. 5), by 1616 two tenements of standard plan (PRO SCI2/11/39 fol. I 5). One tenement lately built leased to Richard Thorne in July 1600 (PRO $\mathrm{SC}_{12 / 1 / 22}$ fol. 3), by 1616 one tenement with small shop and kitchen, otherwise of standard plan (PRO SC $12 /$ I I $_{3} 39$ fol. I S).

Nos. 24-25 Six booths, part of the row of 46 , leased to William Hunt 26 March I 598 (PRO SCI2/I/22 fol. 5), by 1616 two tenements with shop and kitchen, otherwise of standard plan (PROSC12/11/39 fol. I5).

Nos. $21-23$ Parcel of ground (dimensions given) lately booths and now a woodyard, leased to Richard Thome I 8 June I6I2 (PRO SCI2/I/22 fol. 4), by 1616 five tenements, four of these back to back half tenements, otherwise of standard plan (PRO SCI $2 / 1$ I/ 39 fol. I6).

No. 20 Four booths, part of the row of 46 , leased to John Sawell 26 March I 598 (PRO SCI2/1/22 fol. 6), by 1616 two back to tenements of standard plan (PRO SCI2/11/39 fols. 16-17).

Nos. I7-19 Four booths leased to John Grey and four leased to Roger Whitley, both part of the row of 46,26 March 1598 (PRO SCI $2 / 1 / 22$ fols. 5-7), by 1616 three tenements of standard plan (PRO SCi $2 / 1$ I $/ 39$ fol. I7).

Nos. I5-16 Eight booths leased to John Campion, part of the row of 46, 26 March I 598 (PRO SCi2/1/22 fol. 6), by 1616 two tenements of standard plan (PRO $\mathrm{SC}_{12 / 11 / 39}$ fol. 17).

Longtyled House Row, Cloth Fair, $\mathbf{N}$ side, nos. 24-38, built c. I 598 onwards

Nos. 24-27

Fourteen booths, part of the row of 42 called 'the Long Tile Howse', leased to Humfrey Haley 26 March 1598 (PRO SC12/1/22 fol. 4), by 1616 four tenements of standard plan (PRO SCI2/I I/39 fol. I9).

Nos. $28-29$ Parcel of ground (dimensions given) leased to Robert Rawden Io July I6 I 2 (PRO SCI2/1/22 fol. 2), by 1616 two tenements used as one, each of standard plan (PRO SCi $2 /$ i $1 / 39$ fol. 20).

Nos. 30-31 Four booths, part of the row of 42 called 'the long tiled howse', leased to Henry Cox 26 March 1598 (PRO SC $12 / 1 / 22$ fol. 4), by 1616 two tenements of standard plan (PRO SCi2/ I I/39 fol. 20). 
Nos. 32-33 Six booths, part of the row of 42 called 'the long tyle howse', leased to William Guillam 26 March 1598 (PRO SC12/I/22 fol. 2), by I6I6 two tenements of standard plan (PRO SC I $2 / \mathrm{I}_{1} / 39$ fol. 20).

Nos. 34-37 The Court House, eight booths against the Court House (and other property for which see nos. 58-59 Long Lane) leased to Richard Toppin 25 January I 598; also six booths leased to Richard Toppin 27 August 1604 (PRO SC12/1/22 fols. 6 and 4), by 1616 the 'ould Courthouse' and four tenements of standard plan (PRO SCr $2 / 1$ I $/ 39$ fol. 2I).

\section{Close Gate Row, later King Street, built 1598 onwards}

North

Eight booths adjoining to the 'Greene Yarde Gate' leased to Richard Thorne I9 December I 598 (PRO SCr2/I/22 fol. 6), by 1616 four tenements are of standard plan except for one having four chambers not two

South (PRO SC12/11/39 fol. 22).

Fourteen booths part of 22 booths, building timber over the same, leased to Richard Thorne 2 April I 598 (PRO SCI2/I/22 fol. 5), by 1616 six

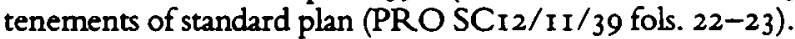

\section{Harthorne Row, no. 22 Cloth Fair and the two houses to the south, built 1598-99}

The row of fourteen booths leased to Thomas Rogers 26 March I 598 (PRO $\mathrm{SC}_{12} / \mathrm{I} / 22$ fol. 2), by 1616 two tenements of standard plan and the Hartshome (PRO SC12/1 1/39 fol. 23).

\section{Newman's Row, Cloth Fair, S side, nos. II-23, redeveloped 1598 onwards}

Nos. 20-21

In I6I6 noted as leased to Matthew Wilkinson is December I 581 , the plot no. 2 I (dimensions given) leased again to Wilkinson is December I 599 (PRO SCI2/1/22 fol. 4), by I6I6 two tenements of standard plan (PRO $\mathrm{SC}_{12} / \mathrm{II} / 39$ fol. 24).

No. 19 The plot of ground (dimensions given) leased to Roger Maden, 26 March 1598 (PRO SCI $1 / 1 / 22$ fol. 2), by 1616 one tenement of standard plan (PRO SCI2/II/39 fol. 24).

No. 18 The plot of ground (dimensions given) abutting upon the east end of the row of 24 booths in Ladies Green, leased to Robert Threeder 26 March I 598 (PRO SC $12 / 1 / 22$ fol. 4 ), by 1616 one tenement of standard plan (PRO SC $12 / 1$ I/39 fol. 24).

Nos. 13-17 In 1616 noted as leased to Richard Toppin 22 February 161 3 ), by 1616 six tenements of standard plan (PRO SCI $2 / 1$ I $/ 39$ fols. 24-25).

Nos. II -12

Booths part of the row of 24 booths in Cloth Fair or Ladies Green, leased to Humfrey Newman 26 March 1598 (PRO SCi2/1/22 fol. 4), by 1616 two tenements of standard plan (PRO SC12/rI/39 fol. 25).

\section{The Old Gallery, the tenements against the Lady Chapel and Choir of the Priory Church}

Nos. I-2

No. 3

No. 4
Four booths part of the row of 22 booths upon the stone house and old galleries, also the stone house, leased to Thomas Rogers 26 March 1598 (PRO SCI2/1/22 fol. 2), by 1616 two tenements, each with cellar and shop, one with chamber and garret, one with chamber (PRO SC I2/I I/39 fol. 26).

Two sheds or booths part of the row of 22, leased to Robert Threeder 26 March 1598 (PRO SC $12 / 1 / 22$ fol. 4), in 1616 one house with a shop, chamber and garret (PRO SCI2/1 1/39 fol. 26).

In 1616 a small cottage with one shop and a garret, held with no. I9 in Newman's Row (PRO SC12/1 1/39 fol. 26). 
No. 5

No. 6

Nos. $7-12$
In 1616 a house with a small shop and a chamber over it, leased to Richard Thorne 20 February 1602 (PRO SCI2/1 I/39 fol. 26).

In 1616 a house with a shop, two chambers and a garret, originally leased to Richard Thome with the 8 booths in Close Gate Row (PRO SC12/11/39 fol. 27).

The upper room called the Old Gallery and 12 booths 'shedwise' against the same, leased to Richard Thome 20 February 1602 (PRO SC $12 / 1 / 22$ fol. 7), in 1616 six tenements all of probably of one room in depth but of varying

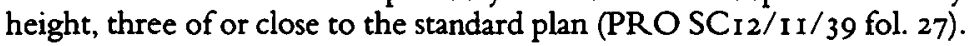

The II houses upon the square in Launders Green, Cloth Fair, N side, nos. 39-42, built 1614-16 (Illus. 21)

No. 42

The plot (dimensions given) leased to William Chapman I4 December 1614, intended to be two houses (PRO SC12/1/22 fol. 2), by 1616 one house with two cellars, two shops, four chambers and two garrets (PRO

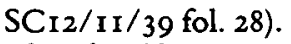

No. $4 \mathrm{I}$

The plot (dimensions given) leased to Richard Cano I4 December I6I4 (PRO SCI $12 / 1 / 22$ fol. I), by I616 one house of standard plan (PRO SC $12 /$ II $/ 39$ fol. 28 ).

No. 40

The plot (dimensions given) leased to Richard Holmes 14 December I6I 4 (PRO SCI $12 / 1 / 22$ fol. I), by 1616 one house of standard plan (PRO SC1 $12 /$ II $/ 39$ fol. 28 ).

Nos. $39, A, B$

The plot (dimensions given) leased to Richard Hide 13 November 1614 (PRO SCi2/1/22 fol. 2), by I6I6 three houses of standard plan (PRO $\mathrm{SC}_{12} /$ I I 39 fol. 28$)$.

Nos. C, D The plot (dimensions given) leased to Thomas Kitchin [illeg.] 16I4 (PRO $\mathrm{SC}_{12} / \mathrm{I} / 22$ fol. 2), by 1616 two houses of standard plan (PRO SCI $1 / 11 / 39$ fol. 29).

Nos. E, F The plot (dimensions given) leased to Peter Heardson I 3 November I6 I4 (PRO SCI $12 / 1 / 22$ fol. 2), by 1616 two houses of standard plan (PRO SC12/ II 39 fol. 29).

Holmes's buildings, no. Io Cloth Fair and the two houses to the south

The I I booths, part of the row of 12 , leased to Edward Holmes 3 February I 598 (PRO SC $12 / 1 / 22$ fol. 6), in I6I6 three tenements of standard plan (PRO SCI2/11/39 fol. 30 ).

\section{From the Church to Smithfield Gate}

Nos. 8-9

Two booths part of 22 booths, and one other booth against the north side of the two [probably the I2th of those otherwise leased to Holmes] leased to Thomas Hutchin 4 December 1607 (PRO SCI $2 / 1 / 22$ fol. 4 ), in 1616 two tenements of standard plan but without cellars, one with kitchen instead of a shop (PRO SCI2/I I/39 fol. 3 I).

Nos. 6-7 In 1616 one double tenement, two shops, two chambers and two garrets leased to Richard Cano c. I 597 (PRO SCI2/I I/39 fol. 3 I).

No. 5 In I6I6 one tenement of standard plan, the shop of two bays, leased to Rowland Lone c. I 597 (PRO SCI2/1 1/39 fol. 31 ).

No. 4

Nos. 2-3 In 1616 one tenement of stand
(PRO SCI $2 / 11 / 39$ fol. 31 ).

Nos. I, A-B In 1616 two tenements of standard plan leased to Rose Maurice c. 1597 (PRO SC $12 / 11 / 39$ fol. 32).

Not noted-houses beyond the fairground in Smithfield $\left(\mathrm{SC}_{12} / \mathrm{II}_{1} / 39\right.$ fols. 32-33) 
Thomas Rogers' Buildings in Launders Green, nos. 43-45 Cloth Fair and buildings behind Nos. 43-45

Two rows of booths etc. leased to Thomas Rogers 25 June 1609 (PRO $\mathrm{SC}_{12} / 11 / 39$ fol. 3 ), in 1616 three tenements of standard plan (PRO SC $12 /$ I I $/ 39$ fols. $34-35$ ).

Behind House where Thomas Rogers lived with four booths enclosed, pump and vault, leased to Thomas Rogers 25 June $1609\left(\mathrm{PRO} \mathrm{SC}_{12} / \mathrm{II} / 39\right.$ fol. 3), in I6I6 complex of buildings arranged around courtyard (PRO SC I $2 /$ I $_{1} / 39$ fols. 34-35).

\section{From Smithfield Gate eastwards, north side of Cloth Fair}

Thirteen booths in Cloth Fair and dwelling house in Smithfield, part of 36 booths in Launders Green, leased to Thomas Kingfeild 20 December 1598 (PRO SC $12 / 1 / 22$ fol. 4), in 1616 one booth or shop, one shop, one tenement of standard plan about eight feet $(2.44 \mathrm{~m})$ square, one cellar with a shop of three bays, three tenements of standard plan, one tenement with a cellar, four chambers and two garrets and cellar with shop and the pump below (PRO SC $12 / 11 / 39$ fols. $35-36$ ).

Parcel of ground below other buildings leased to Richard Whitfeild 24 May I6I4 (PRO SCI2/I/22 fol. S), in I6I6 two booths, the last of the row towards Mr Rogers (PRO SCI2/ I I/39 fol. 36).

Long Lane, redeveloped c. I 598 onwards

The house stables etc. lately erected leased to Edward Walmsley 20 March I 597 (PRO SCI $2 / 1 / 22$ fol. 3), in I6I6 the Green Dragon Inn, together with three tenements of standard plan (PRO SCI $2 / 1$ I/39 fol. 37).

No. 90 In 1616 the house of standard plan leased to Richard Toppin (with his houses in Long Tyled Row) (PRO SC $12 / \mathrm{I} \mathrm{I}_{1} 39$ fol. 38 ).

Nos. $88-89$ Two booths, numbers 38 and 39 , part of the row of 39 , leased to William Rowland 26 March 1598 (PRO SCi $1 / 1 / 22$ fol. 5), in 1616 two tenements of standard plan, no. 89 being over the upper gate into the Clothfair (PRO $\mathrm{SC}_{12} / \mathrm{I}$ I/39 fol. 38).

Nos. $82-87$ Eight booths part of the row of 39 'leading upon the north stone wall', leased to John Stayno 26 March I 598 (PRO SCI2/I/22 fol. 6), in 1616 six tenements of standard plan (PRO SC $12 / \mathrm{II}_{1} / 39$ fols. 38-39).

Nos. $80-8 \mathrm{r}$ Three booths part of the row of 39 'leading upon the north stone wall', leased to William Bell 26 March 1598 (PRO SC $12 / 1 / 22$ fol. 6 ), in 1616 two tenements of standard plan (PRO SC $12 / \mathrm{II}_{1} / 39$ fol. 39 ).

Nos. $77-79$ Three booths part of the row of 39, leased to Garrett Johnson 26 March I 598 (PRO SCI $2 / 1 / 22$ fol. 6 ), in 1616 three tenements of standard plan (PRO SC $12 / 1$ 1 $/ 39$ fol. 39).

Nos. $75-76$

Two booths part of the row of 39, leased to Robert Harrison I February I 598 to be held from 20 August 1598 (PRO SC $12 / 1 / 22$ fol. 3), in 1616 two tenements of standard plan (PRO SC 12/ I I/39 fol. 40).

Nos. 70-74 Eight booths part of the row of 39, leased to Garrett Johnson 26 March I 598 (PRO SC $12 / 1 / 22$ fol. S), in 1616 five tenements of standard plan, no. 73 with the gate (PRO SCi2/1 I 39 fol. 40 ).

Nos. 60-69 Twelve booths part of the row of 39, leased to Edward Holmes 3 February I 598 (PRO SCI $12 / 1 / 22$ fol. 5), in 1616 ten tenements of standard plan (PRO SCI $2 /$ I I $_{1} / 39$ fol. $4 \mathrm{I}$ ).

Nos. $58-59$ Two booths part of the row of 36 and one other booth against these (probably the last of the 39 ) leased (together with the old Court House etc. to Richard Toppin 25 January 1598 (PRO SCi2/1/22 fol. 6), in 1616 two tenements of standard plan, except for no. 59 having an additional two chambers and a garret backwards (PRO SC $12 / 11 / 39$ fol. $4 \mathrm{I}$; see Illus. 2). 
Nos. $53-57$

Nos. 50-52

No. 49
Eight booths part of the row of 36 leased to Peter Bottam 6 February 1598 (PRO SCI2/1/22 fol. 5 ), in 1616 five tenements of standard plan (PRO $\mathrm{SC}_{12} / \mathrm{I}$ 1/39 fol. 42 ).

Six booths part of the row of 36 leased to Edward Yong I 8 February 1594 (PRO SCI $2 / 1 / 22$ fol. 3), in 1616 two tenements with a cellar, shop, hall, two chambers and a garret, one tenement of standard plan (PRO SCI2/I I/ 39 fol. 42; the location of these and no. 49 is not completely certain).

Probably the four booths leased to Thomas Rogers 25 January I609 (PRO $\mathrm{SC}_{12 / 1 / 22}$ fol. 3), in 1616 one tenement with a cellar, shop, hall, two chambers and a garret (PRO SC12/1 I/39 fol. 43).

This paper has been published with the aid of a grant from the Royal Commission on Historical Monuments of England. 